\title{
The Third-Party Doctrine and the Third Person
}

\author{
Simon Stern \\ Version Publisher's Version \\ Citation Simon Stern, "The Third-Party Doctrine and the Third Person" (2013) \\ (published version) 16 New Criminal Law Review 364. \\ Copyright / License New Criminal Law Review, Vol. 16, pp 364-412. ISSN 1933-4192, \\ electronic ISSN 1933-4206. (C) 2013 by the Regents of the University of \\ California. All rights reserved. \\ Please direct all requests for permission to photocopy or reproduce \\ article content through the University of California Press's Rights and \\ Permissions website, http://www.ucpressjournals.com/reprintInfo.asp. \\ DOI: 10:1525/nclr.2013.16.3.364
}

\section{How to cite TSpace items}

Always cite the published version, so the author(s) will receive recognition through services that track citation counts, e.g. Scopus. If you need to cite the page number of the author manuscript from TSpace because you cannot access the published version, then cite the TSpace version in addition to the published version using the permanent URI (handle) found on the record page.

This article was made openly accessible by $U$ of $T$ Faculty. Please tell us how this access benefits you. Your story matters. 


\section{The Third-PARTy Doctrine And The Third Person}

\section{Simon Stern*}

Abstract: According to the third-party doctrine, a person has no reasonable expectation of privacy in information that has been shared with others - including a bank, phone company, or credit card company. The doctrine got its start through an appeal to a locatable observer who corresponds, in literary terms, to a narrator with a limited perspective. This is the kind of perspective that courts have traditionally emphasized when explaining how to assess probable cause. The third-party doctrine turns the limited perspective into an omniscient one. The doctrine takes apparently private conduct and classifies it as public, effectively treating the perspective of the "arresting officer" as if it could encompass large quantities of information, widely distributed in space and time. The discussion here examines a recent defense of the third-party doctrine that similarly collapses the limited and omniscient viewpoints. Then, after exploring the narrative analogy by reference to literary analyses of the omniscient narrator in Victorian fiction, the discussion ends by considering the analogy in relation to contemporary modes of omniscient narration.

Keywords: third-party doctrine $\bullet$ Fourth Amendment $\bullet$ search and seizure $\bullet$ legal theory $\bullet$ common law $\bullet$ law and narrative $\bullet$ narratology $\bullet$ omniscient perspective

Who is the third who walks always beside you?

When I count, there are only you and I together

But when I look ahead up the white road

There is always another one walking beside you

Gliding wrapt in a brown mantle, hooded

I do not know whether a man or a woman

-But who is that on the other side of you?

- T. S. Eliot, The Waste Land ${ }^{1}$

* Associate Professor, Faculty of Law and Department of English, University of Toronto. For comments on earlier drafts, thanks to Lisa Austin, Charles Barzun, Alan Brudner, Vincent Chiao, Gregg Crane, Markus Dubber, Karen Knop, Audrey Macklin, Ed Morgan, Jenny Nedelsky, Mariana Prado, Kent Roach, Mariana Valverde, and Stephen Waddams. Thanks also to Chris Sheridan and Pedram Moussavi for excellent research assistance, and to the New Criminal Law Review's referees for their very helpful advice.

${ }^{1}$ T.S. Eliot, The Waste Land, lines 360-66 (1922) (footnote omitted). 


\section{INTRODUCTION}

Under the aegis of the third-party doctrine, which helps to define a search for Fourth Amendment purposes, the answer to Eliot's question is easy: the vague, hooded presence who always shadows the speaker's companion, and whom the speaker can sense but cannot see directly, is the state. The third-party doctrine informs the analysis of reasonable expectations of privacy under the Fourth Amendment. ${ }^{2}$ Suspects who convey information to a third party, even if only incidentally, lose their right to have it treated as private, and so the police may gain access to it without probable cause or even reasonable suspicion. If the information is not private, the police investigation is not a Fourth Amendment search, but is only an ordinary look that merits no constitutional solicitude. This doctrine applies equally to phone numbers (which must be conveyed to the phone company before the caller is connected), bank account information (which a teller must record), and other transfers of information to service providers. ${ }^{3}$ The courts have said little about the principles anchoring an "objectively reasonable expectation of privacy" 4 in this information, except to assert that by conveying it in this fashion, an actor "assumes the risk" that the recipient may inform the police. ${ }^{5}$ Thus, although Eliot's poem was written in 1922, more than fifty years before the third-party doctrine was born, a contemporary reader might well imagine that the figure, "whether a man or a woman," who is always potentially hovering "on the other side" of any interlocutor, and whose presence becomes clearer after a look into the future, "ahead up the .. . road," is a state actor-

\footnotetext{
${ }^{2}$ The Fourth Amendment to the U.S. Constitution protects "[t]he right of the people to be secure in their persons, houses, papers, and effects, against unreasonable searches and seizures." Its prohibition against "unreasonable" interference has been read to apply only where "a person has a . . reasonable expectation of privacy." Katz v. United States, 389 U.S. 347, 360 (1967) (Harlan J., concurring).

${ }^{3}$ See, e.g., Kyllo v. United States, 533 U.S. 27, 44 (2001) (Stevens, J., dissenting) (utility records); Smith v. Maryland, 442 U.S. 735 (1979) (phone numbers); United States v. Miller, 425 U.S. 435 (1976) (bank records); Couch v. United States, 409 U.S. 322 (1973) (documents provided to accountant); United States v. Phibbs, 999 F.2d 1053, 1078 (6th Cir. 1993) (credit card statements); United States v. Willis, 759 F.2d 1486, 1498 (11th Cir.1985) (motel registration records); United States v. Hamilton, 434 F. Supp. 2d 974, 979-80 (D. Or. 2006) (employment records).

${ }^{4}$ Katz, supra note 2 .

${ }^{5}$ See, e.g., Smith, supra note 3, 442 U.S. at 737.
} 
specifically, a police officer. $^{6}$

The doctrine has been widely criticized on the ground that providing information to entities such as utility companies differs, in normatively important respects, from the other instances in which an objectively reasonable expectation of privacy disappears. ${ }^{7}$ If an item has been left where any member of the public may see it, no third party need be conjured up to explain why the privacy interest has vanished; it is enough to say that what is visible to the public is also open to observation by the police without a warrant. ${ }^{8}$ There is no legerdemain in likening an undercover officer to a false friend who hears a secret: in both instances the defendant means to share the secret and is mistaken in trusting the confidant. ${ }^{9}$ But records held by service providers do not fall into either of these categories. The service provider is not (in any relevant sense) a member of the public, nor someone whom the actor would regard as an interlocutor. Service providers are bureaucratic functionaries, collecting information for billing or accounting

${ }^{6}$ Eliot's original title for the poem was "He Do the Police in Different Voices," a title that links the poem to the Victorian novel and to questions involving impersonation and law enforcement. In Dickens's Our Mutual Friend, the widow Betty Higden, commending the oratorical talents of the foundling she has adopted, explains why she enjoys hearing him read the newspaper: "Sloppy is a beautiful reader of a news-paper. He do the Police in different voices." Charles Dickens, Our Mutual Friend 198 (Marcus Stone ed., 1952) (1865). On The Waste Land and Our Mutual Friend, see Louis L. Martz, Many Gods and Many Voices: The Role of the Prophet in English and American Modernism 30 (1998). On law enforcement and Dickens's fiction, see D.A. Miller, Discipline in Different Voices: Bureaucracy, Police, Family, and Bleak House, in D.A. Miller, The Novel and the Police 58 (1989); see also Philip Collins, The Police, in Philip Collins, Dickens and Crime 196-219 (3d ed. 1994).

${ }^{7}$ See, e.g., Susan Freiwald, First Principles of Communications Privacy, 2007 Stan. Tech. L. Rev. 3; Stephen E. Henderson, Beyond the (Current) Fourth Amendment: Protecting Third-Party Information, Third Parties, and the Rest of Us Too, 34 Pepp. L. Rev. 975 (2007); Susan W. Brenner \& Leo L. Clarke, Fourth Amendment Protection for Shared Privacy Rights in Stored Transactional Data, 14 J.L. \& Pol'y 211 (2006); Gerald G. Ashdown, The Fourth Amendment and the "Legitimate Expectation of Privacy," 34 Vand. L. Rev. 1289, 1315 (1981); Lewis R. Katz, In Search of a Fourth Amendment for the Twenty-First Century, 65 Ind. L.J. 549, 564-66 (1990).

${ }^{8}$ See, e.g., Kyllo, supra note 3, at 42 (2001) ("searches and seizures of property in plain view are presumptively reasonable" because whatever is "knowingly expose[d] to the public . . . is not a subject of Fourth Amendment protection") (Stevens J., dissenting) (internal quotation marks and citations omitted).

${ }^{9}$ See, e.g., Massiah v. United States, 377 U.S. 201, 211 (1964) (defendant's friend "decided to report [their] conversation to the police," and without any prior arrangement between the friend and the police, "it would simply be said that Massiah risked talking to a friend who decided to disclose what he knew of Massiah's criminal activities.”). 
purposes. Typically the data is recorded without human intervention, and on a scale that would make it impractical, if not impossible, for anyone in the organization to examine all of it. ${ }^{10}$

Despite widespread criticism, the third-party doctrine continues to flourish, and there is little reason to imagine that further objections will cause the courts to reconsider. The discussion here, rather than offering a normative critique, presents a narrative analysis, aimed not at effecting legal change but at understanding the conditions that have facilitated the doctrine's growth. Such a project might explore these conditions in their social or psychological aspects, and doubtless that kind of investigation could also help to account for the doctrine's success. ${ }^{11} \mathrm{~A}$ narrative analysis can offer fodder for normative evaluation and social psychological research, but it considers questions that normally escape the attention of commentators who pursue those approaches. As conducted here, it seeks to advance these more conventional forms of legal research, while also pursuing intellectual inquiry for its own sake. That is, while the analysis remains alive to questions about how to justify the legal standards under consideration, it does not make those questions its sole or even primary focus. A legal reform

10 Smith implicitly acknowledged this point in stating that "petitioner voluntarily conveyed numerical information to the telephone company and "exposed" that information to its equipment . ... The switching equipment that processed those numbers is merely the modern counterpart of the operator who, in an earlier day, personally completed calls for the subscriber." Smith, supra note 2, 442 U.S. at 744. The scare quotes around the word "exposed" convey the court's recognition that transmitting information to a computer is not the same as communicating it to a person, with the corollary that humans and machines do not register information with same kind of conscious awareness. This idea is discussed at length in Matthew Tokson, Automation and the Fourth Amendment, 96 Iowa L. Rev. 581 (2010).

${ }^{11}$ Though no such research, to the best of my knowledge, has been undertaken with respect to the third-party doctrine, search and seizure law more generally has benefited from this kind of inquiry; see, e.g., Christopher Slobogin \& Joseph E.Schumacher, Reasonable Expectations of Privacy and Autonomy in Fourth Amendment Cases: An Empirical Look at Understandings Recognized and Permitted by Society, 42 Duke L.J. 727 (1993); Andrew E. Taslitz, The Fourth Amendment in the Twenty-First Century: Technology, Privacy, and Human Emotions, 65 Law \& Contemporary Problems 125 (2002); Orit Gan, Third Party Consent to Search: Analyzing Triangular Relations, 19 Duke Journal of Gender Law \& Policy 303 (2012); Lior J. Strahilevitz, A Social Networks Theory of Privacy, 72 U. Chi. L. Rev. 921 (2005); Henry F. Fradella, Weston J. Morrow, Ryan G. Fischer, \& Connie Ireland, Quantifying Katz: Empirically Measuring "Reasonable Expectations of Privacy" in the Fourth Amendment Context, 38 Am. J. Crim. L. 289 (2011); Jacquelyn Burkell, Deciding for Ourselves: Some Thoughts on the Psychology of Assessing Reasonable Expectations of Privacy, 50 Can. J. Criminology and Criminal Justice 307 (2008). 
project, interested in improving on the "reasonable expectations" formula," would select the narrative features that seem capable of being harnessed or manipulated in the service of that goal. The discussion here, by contrast, assumes that it is worthwhile to study the doctrine's underlying premises even if the result does not readily yield any proposals for reform.

Narrative conventions-particularly those involving the conditions that structure our access to certain kinds of knowledge, or that make a story tellable or render a speaker trustworthy - are so basic to our means of understanding events that we often draw on these conventions, and accept their use by others, without even being aware of it. Thus, for example, as Peter Brooks notes, a court reporter's seemingly artless decision to present the dialogue between the counsel and a witness "in the form of continuous first person testimony" may turn the transcript into "an act of ventriloquism, an example of indirect rather than direct discourse."13 The result is a legal record that displays "good fictional technique, as novelists have long understood, but ... obfuscate[es] ... the issue of [the witness's] understandings and motivations." "14

The modes of narration that we regularly encounter, and the technical means by which they are produced, typically have a history of experimentation, false starts, and slow development that would reveal how much work it takes to create effects that now seem effortless. ${ }^{15}$ An examination of narrative techniques in the

12 Supra note 2.

${ }^{13}$ Peter Brooks, "Narrative Transactions_-Does the Law Need a Narratology?", 18 Yale J. L. \& Hum. 1, 7 (discussing Bumper v. North Carolina, 391 U.S. 543, 547 n.8 (1968)). On this view, the transcript actually includes indirect discourse (the lawyer's words in the witness's mouth) but appears to a reader (e.g., an appellate court) as an example of the witness's direct discourse. Another way to describe the effect would be to say that the transcript attributes the lawyer's direct discourse to the witness. Direct discourse is presented as a verbatim quotation from the speaker, whereas indirect discourse is presented as another's report of what the speaker said. As Anne Banfield explains, "Direct and indirect speech often paraphrase one another: "Mary said, "I am tired," and 'Mary said that she was tired." But despite their apparent synonymy, what is reported of the original speech is not necessarily the same in both." Anne Banfield, Unspeakable Sentences: Narration and Representation in the Language of Fiction 24 (1980). The rest of Banfield's book investigates the differences that flow from these alternative ways of representing speech.

${ }^{14} \mathrm{Id}$.

${ }^{15}$ For a few examples of studies that consider the production of narrative techniques over a long period, see Monika Fludernik, The Fictions of Language and the Languages of Fiction: The Linguistic Representation of Speech and Consciousness (1993); Patricia Meyer Spacks, Novel Beginnings: Experiments in Eighteenth-Century English Fiction (1996); and Jonathan Culpeper \& 
legal context, therefore, can show how doctrinal developments are bound up with extra-legal assumptions that tacitly inform our ideas about issues such as intent, objectivity, and plausibility. Research in this area can also show how varying uses of narrative conventions may produce contrasting results that are ostensibly accounted for on purely doctrinal grounds. To indicate the potential for this kind of inquiry, the following discussion occasionally suggests other contexts (outside of the jurisprudence on search and seizure) in which narrative analysis might shed new light on legal questions. The focus, however, will be on the third-party doctrine and its tacit reliance on an omniscient narrative perspective. ${ }^{16}$

This narrative mode is most closely associated with the Victorian novel. ${ }^{17}$ After the many forms of experimentation (particularly but not exclusively involving first-person narrative) in eighteenth-century fiction, nineteenth-century novelists cultivated a style of narration that provided complete access to the details of the fictional world, including the characters' thoughts, motivations, and half-felt impulses, all of which could be conveyed to the reader by a figure who stands outside the story and who may comment more or less self-consciously on the power that this position affords to control the events described in the plot. ${ }^{18}$

Merja Kytö, Early Modern English Dialogues: Spoken Interaction As Writing (2010). Elaine Scarry, in a similar analysis, describes the process of retroactive effacement as a phase of cultural creation: "[H]aving been made up, ... [a] created thing must then have gone on to a second stage of creation, where the initial work of invention was compounded by an additional process through which reality was conferred on or discovered in it, and the essence of this second stage lay in the making invisible of the traces of its have been created in the first place." Elaine Scarry, The MadeUp and the Made-Real, in Marjorie B. Garber, ed., Field Work: Sites in Literary and Cultural Studies 214, 217 (1996).

${ }^{16}$ For other useful treatments of narrative issues in Fourth Amendment doctrine-though not focusing specifically on questions of narrative perspective-see Jeannie Suk, Is Privacy a Woman?, 97 Geo. L. J. 485 (2009) (rpt. as chap. 5 in Suk, At Home in the Law: How the Domestic Violence Revolution Is Transforming Privacy (2009)); Lawrence Z. Zacharias, The Narrative Impulse in Judicial Opinions, 23 Law \& Lit. 80 (2011); David Sklansky, "One Train May Hide Another": Katz, Stonewall, and the Secret Subtext of Criminal Procedure, 41 U.C. Davis L. Rev. 875, 933 (2008); Peter Brooks, "Inevitable Discovery"-Law, Narrative, Retrospectivity, 15 Yale J. L. \& Human. 71, 100 (2003).

${ }^{17}$ Here I draw on what is probably the most influential of account of narrative omniscience and Victorian fiction, Miller supra note 6. For other discussions, see, e.g., Mark Seltzer, Henry James and the Art of Power (1984); Andrea Goulet, Optiques: The Science of the Eye and the Birth of Modern French Fiction (2006); Albert D. Pionke, Victorian Secrecy: An Introduction, in Victorian Secrecy: Economies of Knowledge and Concealment 1 (2010).

${ }^{18}$ Jonathan Culler helpfully distinguishes the features that combine to make up the omniscient narrator in its classic form: "(1) the performative authoritativeness of many narrative declarations, 
This narrative mode solves various technical problems associated with the novel, but that solution is satisfying because it also solves certain felt needs among readers in search of ways of understanding themselves and their neighborsreaders who find it reassuring to believe in the possibility of certainty and control that the omniscient narrator displays and enacts. Thus if the third-party doctrine can be understood as premised on conditions analogous to those of omniscient narration, that is probably because the doctrine satisfies similar needs, and not because nineteenth-century novels were the only possible means by which jurists could have encountered these features. The vehicles, in both the literary and legal contexts, that combine the certainty and comprehensive vision of the omniscient mode, might be seen as transmitting the memes or mechanisms of cultural software that Jack Balkin has described as "tools of understanding" and "special cases of the ordinary processes and operations of human thought." 19 In exploring this idea, the discussion here does not dwell on the syntactic and formal devices associated with this narrative mode, but instead considers the effects of the omniscient mode in both fiction and law.

Part I provides a short introduction, discussing the potential that narrative analysis - and more specifically, research on narrative perspective-has to offer to legal scholars. This section identifies various instances in which resort to concepts drawn from the study of narrative perspective can furnish insights that bear on the development of legal doctrine. Part II examines a recent defense of the third-party doctrine by Orin Kerr. This defense, though unsupportable on

which seem to bring into being what they describe; (2) the reporting of innermost thoughts and feelings, such as are usually inaccessible to human observers; (3) authorial narration, where the narrator flaunts her godlike ability to determine how things turn out; and (4) the synoptic impersonal narration of the realist tradition." Jonathan Culler, Omniscience, 12 Narrative 22, 26 (2004). He argues the term omniscience "conflates and confuses [these four] factors," and that they "should be separated if they are to be well understood." Id. at 22. In a recent article, Paul Dawson responds that "the idea of omniscience does not conflate and confuse different factors for which the term is used as a dumping ground. Rather, certain works of narrative fiction produce the overall effect we have labelled omniscience by combining all four phenomena Culler identifies (and others, such as temporal range)." Paul Dawson, The Return of Omniscience in Contemporary Fiction, 17 Narrative 143, 146 (2009). Dawson proposes that rather than dispensing with the concept as a jumble of features better considered distinctly, we should recognize the value of "the term omniscient narration as a label only for . . . those works which actualize a panoramic intrusive narrator, which perform omniscience, rather than those narratives which report without comment, or in which commentary does not reveal a sense of the narrator's personality." Id. at 148.

${ }^{19}$ Jack Balkin, Cultural Software: A Theory of Ideology (1998). 
normative grounds, shares some of the narrative assumptions underlying the thirdparty doctrine itself, and helps to bring those assumptions into prominence. Hence after subjecting this account to a conventional style of critique, the discussion shifts in Part III to a narrative lens, showing how the doctrine endows the police with the kind of narrative omniscience that some literary critics have associated with the Victorian novel. Finally, the last section considers how this analogy might operate with respect to contemporary modes of omniscient narration.

The third person in Eliot's poem, quoted at the outset, is a visible if only obliquely glimpsed figure, one whose physical presence is noticeable. According to the justification for the third-party doctrine explored here, however, one of its virtues is that it allows for methods of police evidence-gathering which are themselves substitutes for the real-time surveillance that would be necessary if the suspect were operating openly. A suspect might notice someone tailing hermight register the gliding, hooded figure just as Eliot's speaker does-but suspects are most unlikely to be aware that a police officer is trying to obtain their phone or bank records. Thus, unlike the third person in "The Waste Land," the third person of this essay should be associated with the third person of omniscient narration, which designates not a visible figure but a means of revealing information and modeling access to knowledge.

\section{LAW AND NARrative Perspective}

Peter Brooks has asked whether the law needs a narratology. ${ }^{20}$ Commentators on "law and narrative" usually understand the label to refer to law and narrative structure, or law and narrative detail, ${ }^{21}$ but as Brooks has made clear in at least one version of his query, an answer might also discuss issues such as law and

\footnotetext{
${ }^{20}$ Brooks, Narrative Transactions, supra note 13 . Brooks has hinted at the answer in various other writings. See Brooks, "Inevitable Discovery," supra note 16 at 100 (“[T] he legal analytical toolkit could do well to include some 'narratology."'); Peter Brooks, Policing Stories, in Law's Madness 29, 43 (Austin Sarat et al. eds. 2003) ("Law may need a narratology."); Peter Brooks, Narrative in and of the Law, in A Companion to Narrative Theory 415, 424 (James Phelan \& Peter J. Rabinowitz eds., 2008) ("Law, one might say, needs a narratology."); Peter Brooks, Narrativity of the Law, 14 Law \& Lit. 1, 1 (2002) ("[A]ssertions [that] seem unimpeachable to literary narratologists[] . . . remain heretical within the world of the law, which does not overtly recognize 'narrative' as a category in the process of legal adjudication.").

${ }^{21}$ For examples, see Simon Stern, Detecting Doctrines: The Case Method and the Detective Story, 23 Yale J.L. \& Human. 339, 339-41 (2011), and the sources cited there.
} 
narrative perspective. ${ }^{22}$ When the question is framed in that fashion (and without excluding these other ways of thinking about relations between law and narrative), an answer might consider how lawyers and judges import assumptions about narrative perspective that they have acquired-consciously or not-from media such as novels, television, and the internet. ${ }^{23}$ Nor do these ideas move only in one direction: once we have seen how narrative paradigms that remain implicit in one medium can be absorbed and reflexively transferred to another medium, it becomes apparent that legal doctrines may incorporate these acquired perspectives and may even revise them, generating new ones which, in turn, become available for transfer to other media in a feedback loop. ${ }^{24}$ Besides borrowing from genres that conventionally inform our views about narrative, lawyers and judges might also spawn narrative conventions of their own. Thus, for example, one of the unusual temporal features of legal judgments involves their reliance on a present imperfect tense that is used to align doctrines originating at widely disparate times, and that makes these doctrines appear coterminous in an ongoing present. ${ }^{25}$ Examination of this feature might help to identify some of the motives for the growing popularity of present-tense narration

${ }^{22}$ Peter Brooks, Literature as Law's Other, 22 Yale J.L. \& Human. 349, 360 (2010) ("The analytic tools of

narratology, including questions of point of view, voice, implied audience, and the fundamental distinction between story and narrative discourse ... . are almost never found in the law, even in those cases that seem urgently to call for such attention.").

${ }^{23}$ These forms are not analogous; rather, they may each incorporate and reflect distinct narrative structures and perspectives - a point that has been largely ignored in scholarship on law and film, which tends to treat movies as if they were simply renditions of novels with no generically distinct features. For a useful discussion of distinctions between types of narrative in various media, see Jay David Bolter \& Richard Grusin, Remediation: Understanding New Media (1999).

${ }^{24}$ Others have discussed this effect primarily in terms of a feedback loop based on the content portrayed in a certain medium (e.g., movies about trials) and the legal system. For helpful discussions, see, e.g., Richard K. Sherwin, When Law Goes Pop: The Vanishing Line between Law and Popular Culture (2002); Susan Bandes, We Lost It at the Movies: The Rule of Law Goes from Washington to Hollywood and back Again, 40 Loy. L.A. L. Rev. 621 (2007). Conditions governing narrative access may be subject to a similar process, which often occurs at a level below our conscious apprehension.

${ }^{25}$ As Richard Danzig puts it, using a horticultural metaphor to describe the first-year law curriculum, "cases are normally treated like doctrinal fruits on a conceptual tree: some bulk large, some are almost insignificant[] . . but all are quite erroneously treated as though they blossomed at the same time, and for the same harvest." Richard Danzig, Hadley v. Baxendale: A Study in the Industrialization of the Law, 4 J. Leg. Stud. 249, 250 (1975). 
in fiction since the mid-nineteenth century. ${ }^{26}$

Narrative perspective may have particularly salient implications for Fourth Amendment jurisprudence, which seeks to gauge the legality of searches by returning to a particular moment and establishing the specific details that were "available to the officer" ${ }^{\prime 27}$ at that time. The ambiguity of this formulation already hints at the complicated task of such analysis, which in narrative terms may conflate perceptions barely at the edge of the consciousness ("available" in the sense that they are capable of being perceived) with those that have been actually registered and contemplated. ${ }^{28}$ In her influential study of narrative perspective, Dorrit Cohn marks this distinction by describing the "potential-actual relationship between narrated monologue and verbal formulation"- the relationship between details that may be presented to a reader as "the mind's vague ruminations" and the perceptions that have actually "led to conceptual expression" in a character's mind or speech. ${ }^{29}$ Recent work on hindsight bias in the law of search and seizure shows why it is difficult to monitor that distinction, ${ }^{30}$ but research on narrative perspective could also help to explore the problems that arise in this context. Such analysis might show how courts shuttle between these two poles, using narrative techniques that paper over the distinction, so as to conceal from themselves a problem they are reluctant to investigate. With a clearer understanding of what it means for information to be "available" (and perhaps aided by work in other

${ }^{26}$ Questions about temporal alignment have received little attention in legal scholarship except among forensic sociolinguists. For some useful discussions of present-tense narrative by literary scholars and anthropologists, see, e.g., Christian Paul Casparis, Tense without Time: The Present Tense in Narration (1975); Kazunari Miyahara, Why Now, Why Then?: Present-Tense Narration in Contemporary British and Commonwealth Novels, 39 J. Narrative Theory 241 (2009); Theo Damsteegt, The Present Tense and Internal Focalization of Awareness, 26 Poetics Today 39 (2005); Kirsten Hastrup, The Ethnographical Present: A Reinvention, 5 Cultural Anthropology 45 (1990).

27 Texas v. Brown, 460 U.S. 730, 742 (1983).

${ }^{28}$ This distinction helps to show how arrest pursuant to a warrant differs from a warrantless arrest: the warrant requires the police to state expressly what they know, and therefore serves as a guard against hindsight bias, which may serve retroactively to find significance in details that were available but only barely noticed at the time of the arrest. For discussion of this point, see Andrew E. Taslitz, Foreword: The Death of Probable Cause, 73 Law \& Contemp. Probs. i, vii (2010).

${ }^{29}$ Dorrit Cohn, Transparent Minds: Narrative Modes for Presenting Consciousness in Fiction 104 (1978).

${ }^{30}$ See, e.g., Jeffrey J. Rachlinksi et al., Probable Cause, Probability, and Hindsight, 8 (supp. s1) J. Empirical Legal Stud. 72 (2011); Slobogin \& Schumacher, supra note 11, at 765-68; Taslitz, supra note 28 , at vii. 
fields, such as cognitive psychology), courts would be better positioned to apply this requirement in determining probable cause. ${ }^{31}$

These issues, however, are hardly restricted to Fourth Amendment law. Trials are often structured around efforts to establish what information was known, or available to be known, at a particular time, and by whom. The observation may seem banal, given that scholars of law and literature often make a point of insisting that trials are inherently narrative events, yet in substantiating the point, much of that work ignores the questions that students of narrative tend to ask. Rather than inquiring into the conditions that govern the visual and verbal means of presenting information, comments about trials as narrative quickly give way to analyses of trials as rhetorical events, or discussions of vivid details that are assumed to have something to do with narrative because, after all, their prominence ensures that these details have a significant narrative impact. ${ }^{32}$ Even when scholars do examine trials in terms of narrative perspective, the goal is usually to show how any particular view of the events must be partial, must be situated from a particular standpoint, leading to inconsistency and apparent conflict among witnesses. Research on narrative perspective could significantly refine these insights, helping us understand how we come to accept, as plausible or natural, certain assumptions about narrative access to others' thoughts and motives, and how we come to treat certain ways of paraphrasing quoted speech, or certain ways of synthesizing testimony, as persuasive because of the narrative frames that the speaker uses to define the hearer's perception of that information.

What applies to courtroom advocacy and the production of evidence may also apply to the presentation of events and legal doctrines in judgments. It is a truism that majority and dissenting opinions, like opposing counsel in court, tend to offer contrasting descriptions of the events that ultimately blossomed into full-scale litigation. But if these descriptions differ in their selection of important details,

${ }^{31}$ One of Brooks's analyses of law and narrative ventures in this direction. His discussion of the "inevitable discovery" rule proposes that when the story of a search ends with the discovery of incriminating information, that narrative conclusion will distort the hearers' perceptions about other possible outcomes, and hence will lead to judges to err on the side of treating the result as “inevitable." Brooks, Inevitable Discovery, supra note 20. Though Brooks does not refer to the research on hindsight bias, and though he emphasizes narrative structure rather than narrative perspective, both of these concepts could help to explore the argument further.

${ }^{32}$ For an important study of visual frames that ranges beyond these matters, see Richard K. Sherwin, Visualizing Law in the Age of the Baroque: Arabesques and Entanglements (2011). 
they may also differ in their narrative alignment with certain actors or doctrines. Tropes of omniscience are familiar from discussions that treat legal history as a story in which law "works itself pure" or slowly gravitates towards sound and coherent principles. ${ }^{33}$ These are accounts in which no unified viewer is invoked to explain how the slow and incremental movement towards consistency occurs, but - at least when they are presented self-consciously by judges - these accounts implicitly treat the observer of this very tendency as inhabiting an omniscient mode, capable of collecting disparate cases and discerning the larger pattern they help to form. This mode defines an authoritative and disinterested position, by contrast with the position of an observer who places herself closer to ground, as if immersed in the territory to be charted. Analysis of the contexts in which judges use this convention might thus help to explain why some efforts at doctrinal innovation are more successful than others. Of course, a thoroughgoing survey of doctrinal change will generally be more persuasive than one that appears narrow and partial, but even a wide-ranging analysis may appear more or less objective depending on whether the speaker occupies a standpoint beside or above the developments being described.

Narrative perspective remains a comparatively understudied topic in research on law and literature, perhaps because questions involving focalization, proximity, and point of view sound as if they may offer more of the barren, bloodless, technical distinctions that law professors are usually trying to escape when they turn to literature. ${ }^{34}$ But if these distinctions are technical, they also offer a set of powerful and sophisticated tools that can help to refine our

\footnotetext{
${ }^{33}$ The phrase, which originated with Lord Mansfield, seems to have made its way into the modern legal phrasebook through Lon Fuller's rendition, in the final sentence of The Law in Quest of Itself (1940): "The common law works itself pure and adapts itself to the need of a new day." Id. at 140. In a case that helped to establish the "best evidence" rule (in the context of a dispute over the admissibility of evidence given under oath by a Hindu), Mansfield had written that "the common law, that works itself pure by rules drawn from the fountain of justice, is for this reason superior to an action of parliament." Omychund v. Barker, 26 Eng. Rep. 15, 23 (Ch. 1744).

${ }^{34}$ Twenty-five years ago John D. Ayer observed, when discussing the motives for "speak[ing], ... teach[ing], ... and writ[ing] about "law and literature," that "[a] lawyer might sojourn in the realm of literature just as he might take a vacation in Paris, carrying back a few good stories and the edifying conviction that he had somehow bettered himself." John D. Ayer, The Very Idea of "Law and Literature", 85 Mich. L. Rev. 895, 895 (1987). His account still holds good as a description of much of the work in this area. For some recent discussions of this tendency, see Brooks, supra note 22; Rob Atkinson, What Is It Like to Be Like That? The Progress of Law and Literature's “Other” Project, 43 Stud. L. Pol. \& Soc'y 21 (2008).
} 
understanding of how legal doctrines and texts work. The ways in which narratives control access to the information they present often depend on subtle techniques whose effects we may not even be able to recognize without the tools of narratology. Tracing a rule's origins and development or giving a short summation with a string cite, describing the parties from a perspective within or above their world - these are differences that we may not consciously register, but they can significantly affect our perception of a judgment's doctrinal exposition. Narratology has the potential to explain many of our intuitive responses to legal narratives - responses that we may simply take for granted as reactions to the explanatory force of the analysis. Rather than facilitating a turn away from law, the study of narrative perspective can suggest new ways of studying the very technicalities that have traditionally provided the essential basis for legal analysis. ${ }^{35}$ The following discussion seeks to apply this mode of analysis to a widely criticized doctrine in the law of search and seizure.

\section{The Fourth AMEndment AND THE ThIRD-PARTy DoCTRINe}

The third-party doctrine got its start through an appeal to a locatable observer with a perspective that corresponds, in literary terms, to that of an embodied and identifiable narrator who inhabits the same world as the other characters in the story's plot. Such a figure does not have potentially limitless knowledge about the world, but instead has the limited perspective that courts have traditionally emphasized when explaining how to assess probable cause, which depends "not on the facts as an omniscient observer would perceive them but on the facts as they would have appeared to a reasonable person in the position of the arresting officer-seeing what he saw, hearing what he heard." ${ }^{36}$ In narrative terms, a perspective aligned with the consciousness of a single actor-whether a character in the story or a narrator whose knowledge is confined to what a particular character can perceive - is said to be focalized, ${ }^{37}$ and this is the model that has

35 Annelise Riles has similarly argued that humanistic legal studies should engage with legal technicalities rather than evading them. Annelise Riles, A New Agenda for the Cultural Study of Law: Taking on the Technicalities, 53 Buff. L. Rev. 973 (2005).

${ }^{36}$ United States v. Parra, 402 F.3d 752, $763-64$ (7th Cir. 2005) (internal quotation marks omitted) (citing Mahoney v. Kesery, 976 F.2d 1054, 1057 (7th Cir. 1992)); see also United States v. Rivera, 370 F.3d 730, 733 (8th Cir. 2004) (same) (citation omitted); State v. Steelman, 94 S.W.3d 102, 115 (Tex. Crim. App. 2002) (same) (internal quotation marks and citation omitted).

${ }^{37}$ See, e.g., Gerard Genette, Narrative Discourse Revisited 72-78 (1988); see also Andreas Kiblitz, Realism as a Poetics of Observation, in What is Narratology? 99, 128 (Tom Kindt \& Hans-Harald 
traditionally governed courts' views about information that gives rise to probable cause. Yet the doctrine has developed in a way that breaks free of this confined viewpoint and pushes in the direction of a third-person omniscient perspective.

The third-party doctrine is a product of the approach to privacy inaugurated in 1967 by Katz v. United States, ${ }^{38}$ which held that conduct is not protected by the Fourth Amendment unless the actor "exhibited an actual (subjective) expectation of privacy and[] . . . the expectation [was] one that society is prepared to recognize as "reasonable." 39 Over the next decade, Katz provided the doctrinal grounding for a series of decisions holding that individuals have no reasonable expectation of privacy in information shared with service providers such as the phone company, the utility company, a bank, or an accountant. ${ }^{40}$ More recently, $K a t z$ has been applied to information sent via Internet Service Providers, with mixed results. ${ }^{41}$ The nub of the Katz test is its reasonableness requirement, yet another offshoot of the tremendously productive "reasonable person" standard that grew like kudzu in the garden of the nineteenth-century common law. ${ }^{42}$ Often, a defendant's expectation of privacy can be evaluated simply by reference to the place where the evidence was kept, so that the difference between the dashboard and trunk of a car may resolve the issue. Commentators have been less enthusiastic when the same conclusion is applied to bank and phone records, which must necessarily be shared with a service provider. Many regard it as

Muller eds. 2003) ("Focalized narration ... . seems to correspond to a social model which sees observation as one of its key components.").

${ }^{38}$ Supra note 2.

${ }^{39}$ Id. at 361 (Harlan, J., concurring). Though set out in a concurrence, this formulation was soon embraced by federal appellate courts as Katz's holding (see, e.g., Government of Virgin Islands v. Berne, 412 F.2d 1055, 1061 (3d Cir. 1969); United States v. Hitchcock, 467 F.2d 1107, 1108 (9th Cir. 1972) (per curiam)), and eventually by the Supreme Court (see Smith v. Maryland, 442 U.S. 735, 740 (1979)).

${ }^{40}$ See supra note 3.

${ }^{41}$ See, e.g., United States v. Hambrick, 225 F.3d 656, (4th Cir. 2000); United States v. Pilozzi, 549 U.S. 308, 391-92 (E.D.N.Y. 2008); see also Tokson, supra note 10.

${ }^{42}$ See, e.g., Vaughan v. Menlove, 132 Eng. Rep. 490, 493 (C.P. 1837) (using the "reasonable man" to measure negligence in tort); Judge Harvey A. Schneider, Katz v. United States: The Untold Story, 40 McGeorge L. Rev. 13, 18 (2009) (explaining that the author, as a young lawyer preparing to argue Katz in the Supreme Court, "reflected on [his] Torts class" and concluded that the test for Fourth Amendment privacy should rely on the "reasonable person"). Katz was a late extension of the standard, whose earlier growth is discussed in Michael Lobban, "Common Law Reasoning and the Foundations of Modern Private Law," 32 Austl. J. Leg. Phil. 39, 52-66 (2007) and David Ibbetson, A Historical Introduction to the Law of Obligations 164-177 (1999). 
normatively acceptable for an eavesdropper in the park to pass along the news she overheard, but as normatively unacceptable for a bank teller, entrusted with someone's financial information, to do the same thing. ${ }^{43}$ Hence while courts have repeatedly held that "the police cannot reasonably be expected to avert their eyes from evidence . . . that could have been observed by any member of the public,"44 this maxim does not easily account for evidence that could have been observed only by a few persons who were specifically authorized to see it, and who might be liable for breach of fiduciary duty, or worse, if they revealed it to others. ${ }^{45}$

The courts, in rationalizing the doctrine, have implicitly likened the service provider to a "false friend," effectively collapsing the distinction between subjective and objective perceptions. ${ }^{46}$ As courts have explained, the information conveyed to a service provider is stripped of any privacy interest on the sender's part, because the functionary might decide to pass the information to others. ${ }^{47}$ This approach dispenses with the individual perspective that drives the "public access" and "false friend" models of access to information, because the service provider cannot be said to register the content in the way that those models contemplate. Normatively, the third-party doctrine has generated controversy because consumers have little choice about using phones and similar utilities, and so arguably they have been conscripted into communicating information in a way that may be used against them. ${ }^{48}$

${ }^{43}$ See, e.g., Slobogin \& Schumacher, supra note 11.

${ }^{44}$ Kyllo, supra note 3, at 45 (Stevens, J., dissenting) (internal quotation marks and citation omitted).

${ }^{45}$ See Sherry F. Colb, What Is a Search? Two Conceptual Flaws in Fourth Amendment Doctrine and Some Hints of a Remedy, 55 Stan. L. Rev. 119, 122 (2002) (the third-party doctrine "treats exposure to a limited audience as morally equivalent to exposure to the whole world").

46 For a useful discussion of doctrinal contexts in which courts make the opposite move, hypothesizing a "reasonable officer" who would (under an objective standard) know less than the officer at the scene, and whose actions would be justified because his reasonable beliefs would not be vitiated by particular details that the arresting officer actually knew, see Craig M. Bradley, The Reasonable Policeman: Police Intent in Criminal Procedure, 76 Miss. L.J. 339 (2006).

47 See, e.g., Miller, supra note 2, 425 U.S. at 443 ("The depositor takes the risk, in revealing his affairs to another, that the information will be conveyed by that person to the Government.") (citation omitted); Smith, supra note 2, 442 U.S. at 744 (someone who uses a phone "assume[s] the risk that the company [will] reveal to police the numbers he dial[s].").

48 See, e.g., Smith, supra note 2, at 749-50 (Marshall, J., dissenting) ("It is idle to speak of 'assuming' risks in contexts where, as a practical matter, individuals have no realistic alternative"); Stephen E. Henderson, Nothing New Under the Sun? A Technologically Rational Doctrine of Fourth Amendment Search, 56 Mercer L. Rev.. 507, 520 (2005) ("Miller had no 
Until recently, the widespread criticisms of the third-party doctrine had not elicited any justification in rebuttal. However, in an article published in 2009, Orin Kerr defends the doctrine on two grounds. ${ }^{49}$ First, he argues, it monitors the distinction between public and private behavior by denying wrongdoers the ability to shift their conduct from the first category to the second in order to conceal their activities. As Kerr explains, the doctrine "maintain[s] the technological neutrality of Fourth Amendment rules," preventing criminals from hiding behind the shield of "privacy" when they use phones, bank accounts, the mail, and other substitutes for direct action, conducted openly. ${ }^{50}$ By operating through third parties in this fashion, criminals remove "from public observation" what would otherwise be "open and public portions of crimes," and this shift, if permitted, would constitute an "end-run around the traditional Fourth Amendment balance." 51 Someone who would once have had to travel personally to execute a plan, or to store and retrieve assets, or to meet associates, today may enlist technology to achieve the same ends. All this conduct, which might have been seen by a police officer who had a reason to keep an eye on the suspect, could now occur clandestinely without risk of observation if it were legally deemed to be private. The phone conversation and the contents of the envelope remain private, but the information that represents the suspect's substitutive efforts - the number that was dialed, the address on the envelope-are treated as public. That is what Kerr seems to mean by "technological neutrality": by reversing the cloaking effect of these actions, the third-party doctrine maintains the "traditional Fourth Amendment balance" and "helps ensure that the Fourth Amendment rules that apply to crimes committed using third parties are roughly equivalent to the rules that apply to crimes committed without them." 52

choice but to surrender his information to the bank . . . to transact business there."); Daniel J. Solove, Digital Dossiers and the Dissipation of Fourth Amendment Privacy, 75 S. Cal. L. Rev. 1083, 1089 (2002) ("[R]ecords containing personal information [are] necessary to establish an account and record of our transactions, preferences, purchases, and activities" concerning "numerous relationships with professionals (doctors, lawyers, accountants), businesses (restaurants, video rental stores), merchants (bookstores, mail catalog companies), publishing companies (magazines, newspapers), organizations (charities), financial institutions (banks, investment firms, credit card companies), landlords, employers, and other entities (insurance companies, security companies, travel agencies, car rental companies, hotels).").

${ }^{49}$ Orin S. Kerr, The Case for the Third-Party Doctrine, 107 Mich. L.R. 561 (2009).

${ }^{50} \mathrm{Id}$. at 564.

${ }^{51}$ Id.

${ }^{52}$ Id. at 565. 
Second, Kerr explains that the third-party doctrine provides ex ante clarity by ensuring that when police officers gain access to information, they know that it will be deemed admissible (or not) by virtue of its surrounding context. The doctrine ensures that "Fourth Amendment protection for information matches the Fourth Amendment protection for the environment in which it is stored." ${ }^{, 53}$ That is, when the police encounter incriminating information, its location (rather than the information itself, or the route by which it arrived) tells them what degree of privacy it deserves. The contents of a letter that passes through the mail must be treated as private while the letter is making its journey, but the same letter, now "opened, and sit[ting] on the recipient's desk at home in a stack of other letters and other papers," merits the same degree of protection as those other documents. ${ }^{54}$ Therefore the police need ask only whether they discovered the letter in a place that renders it public, or whether they may have access under "the usual rules of home searches," as a general matter, rather than undertaking the nearly impossible task of determining whether each document is private or not by virtue of its particular historical trajectory. ${ }^{55}$

On closer inspection, neither of these arguments turns out to provide a normative justification for the third-party doctrine; however, they provide a valuable descriptive account of its effects - a descriptive account that offers significant insights into the workings of Fourth Amendment law. To see why this account lacks normative force, we might ask what is "traditional" about the Fourth Amendment balance that substitutive conduct is said to destabilize. ${ }^{56}$ The traditional balance is the one that would have obtained when there could be no resort to substitutive technology. ${ }^{57}$ When criminals did not have that option, it is

${ }^{53} \mathrm{Id}$.

${ }^{54}$ Id. at 582.

55 Id.

${ }^{56}$ Kerr, supra note 49, at 565; see text accompanying supra note 52.

${ }^{57}$ For a critique on this point, see Erin Murphy, The Case against the Case for the Third-Party Doctrine: A Response to Epstein and Kerr, 24 Berk. Tech. L.J. 1239, 1241-43 (doubting that "such 'substitution effects' really take place, at least not on the scale and to the degree that would justify forfeiting all third-party protection," because "[a] lot of crime does not come with an obvious technological alternative, or to the extent that outsourcing is possible, it fundamentally alters the nature of the offense."). Similarly, Christopher Slobogin observes, in a response to Kerr's more recent formulation of his equilibrium-adjustment theory, that "[b]ecause there is no Year Zero baseline for either special needs situations or white-collar crime investigations, there is nothing in 
suggested, the balance between policing and privacy would have found a different fulcrum than it currently does, because a significant amount of conduct that now is concealable would have been visible to others. The characterization of this balance as "traditional" suggests not simply that it tracks some ideal view of the balance, but that it identifies a balance that obtained historically at some point (or at least was more nearly achieved), because a "tradition" must originate somewhere; otherwise it refers to a mythical ideal that cannot have been lost because it never existed. ${ }^{58}$ The description of a traditional balance that has been destabilized, however, applies modern concepts to an archaic world and mixes them in a way that confuses the issues. First, privacy has been a highly variable and contested concept over the period since the ratification of the Bill of Rights, ${ }^{59}$ and the kinds of information, places, and actions that are regarded as private today are not the same as those that would have been private in the later eighteenth century or at some hypothetical earlier date. ${ }^{60}$ Some historians argue that modern

equilibrium-adjustment theory that answers these questions." Christopher Slobogin, An Original Take on Originalism, 125 Harv. L. Rev. F. 14, 20 (2011).

${ }^{58}$ Hence the problem is not solved by replacing the idea of a "traditional" balance with one notionally originating at "Year Zero, an imaginary time before the introduction of tools both to commit crimes and to catch wrongdoers." Orin Kerr, An Equilibrium-Adjustment Theory of the Fourth Amendment, 125 Harv. L. Rev. 478, 482 (2011). As noted below (see text following note 77), such an account must nevertheless explain why the balance corresponding to that moment can be justified as the right one, rather than merely a happenstance byproduct of legal requirements. Moreover, as we will see (see note 84 and text accompanying notes 81 - 84), without an explanation of what counts as a "tool[] . . . to commit crimes" or as substitutive technology, it is impossible to specify concretely the conditions that apply at "Year Zero" and hence impossible to know what balance would obtain at that time.

${ }^{59}$ Slobogin makes a related point when he observes that, assuming we could accurately specify the understanding of privacy that correlates with the factual circumstances in "Year Zero" (or in 1789, or in 1886), a commitment to maintaining the equilibrium extant at that time would "lock[] us in to a view of privacy and autonomy interests that does not take into account changing norms." Slobogin, supra note 57, at 21 . He adds, "[D]ifferences between early and modern norms, if they do exist, should count for something in modern day Fourth Amendment jurisprudence.” Id.

${ }^{60}$ Needless to say, if the balance reflects an earlier age, a "world without tools," as Kerr suggests in his more recent discussion (see Kerr, supra note 58, at 483), then privacy becomes even an even more heavily contested concept. On the historical emergence of ideas about privacy in the Western world, considered variably in terms of spaces, personal details, and physical integrity, see Philippe Ariès \& Georges Duby, A History of Private Life (5 vols., 1987-91); Barrington Moore, Privacy: Studies in Social and Cultural History (1984); Diana Webb, Privacy and Solitude in the Middle Ages (2007); Mary Thomas Crane, Illicit Privacy and Outdoor Spaces in Early Modern England, 9 J. Early Modern Cultural Stud. 4 (2009); Patricia Spacks, Privacy: Concealing the EighteenthCentury Self (2003); Milette Shamir, Inexpressible Privacy: The Interior Life of Antebellum 
conceptions of privacy - discerned by Justice Douglas as the underlying source of various constitutional protections, ${ }^{61}$ defended by Warren and Brandeis in their famous Harvard Law Review article ${ }^{62}$ - did not come into being until the nineteenth century. ${ }^{63}$ Second, there were no police forces (in the relevant sense) in England or the United States until several decades into the nineteenth century, and their roles and procedures - and accordingly their needs-have undergone significant change over time. ${ }^{64}$ Before that time, prosecutions were largely left to victims and their helpers, and the courts were willing to accept virtually any evidence they could produce, no matter how it had been acquired. ${ }^{65}$ It remains

American Literature (2006); Victoria Rosner, Modernism and the Architecture of Private Life (2003); Deborah Nelson, Pursuing Privacy in Cold War America (2002).

${ }^{61}$ Griswold v. Connecticut, 381 U.S. 479, 484-85 (1965).

${ }^{62}$ Samuel Warren \& Louis D. Brandeis, The Right of Privacy, 4 Harv. L. Rev. 193 (1890).

${ }^{63}$ See, e.g., Shamir, supra note 60, at 2 (noting that "the middle decades of the nineteenth century, roughly between 1830 and 1870 " saw "a complete overhaul of the meaning of privacy.") (footnote omitted); Bryan S. Turner, Privacy, in 2 The Social Science Encyclopedia 1154 (2d ed., Adam Kuper \& Jessica Kuper eds., 2003) ("Privacy as a value is often regarded as an essentially modern development, emerging out of the liberalism of nineteenth-century writers like J.S. Mill") (citation omitted); Lawrence Friedman, Guarding Life's Dark Secrets: Legal and Social Controls over Reputation, Propriety, and Privacy 258 (2007) ("Privacy, as idea and reality, is the creation of a modern bourgeois society. Above all, it is a creation of the nineteenth century.").

${ }^{64}$ See George C. Thomas III, Time Travel, Hovercrafts, and the Framers, 80 Notre Dame L. Rev. 1451, 1462 (2004) (“Almost nothing about the Framers' Fourth Amendment is relevant to modern policing. . . . For example, the common law limited arrests and searches in ways that would be unacceptable in the world of modern policing. The cornerstone of common law arrest and search procedure was not a prediction of probability that the suspect was involved in criminal activity. A lawful arrest or search could not occur in the absence of proof that a crime in fact had been committed.") (footnotes omitted); see also Thomas Y. Davies, Correcting Search-and-Seizure History, 77 Miss. L.J. 1, 187 n.589 (commenting on the decision in Beckwith v. Philby, 108 Eng. Rep. 585 (K.B. 1827), which allowed police officers to arrest on probable cause, rather than requiring proof of crime; according to Davies, "The expansion of a peace officer's discretionary arrest authority in Beckwith may well have been a crucial step in making a police force feasible.").

${ }^{65}$ Thus, for example, while questions about privacy played an important role in Wilkes v. Wood, 19 Howell's State Trials 1153 (C.P. 1763) and Entick v. Carrington, 19 Howell's State Trials 1029 (C.P. 1765), these cases did little to protect the privacy of suspects in criminal prosecutions. As William Stuntz observes,

Protecting privacy in cases like Entick and Wilkes had no effect on the mass of ordinary criminal cases. . . Entick and Wilkes . . . were civil actions for damages against public officials. They created no entitlement enforceable in a criminal case; the exclusionary rule was unknown at the time. . . . [I]n the civil damages action, the constable could defend himself by showing that the search was successful, even if it was also illegal. . . . [Moreover,] prearrest searches and seizures played a small role in the investigation of ordinary crimes. There were no police forces, so the 
true today that information acquired by private actors (when not serving as agents of the police) is rarely subject to exclusion, but the point is that before the nineteenth century, it was expected that such information would be used against a criminal defendant. ${ }^{66}$ The evidentiary basis of the prosecution's case did not reflect a normative balance of policing and privacy, because (with minor exceptions) there were no police to collect evidence, and privacy was not even a consideration to be balanced. ${ }^{67}$ Third, banks and the mail both predate the Fourth Amendment, and so there is no historical sense in which the arrival of these substitutes for public behavior can be said to have altered a previously existing balance between policing and privacy_particularly when both of those concepts were in flux. ${ }^{68}$ According to the theory that describes substitutive conduct as upsetting a traditional balance, the factors to be balanced - policing and privacyreflect modern norms, yet the baseline of "traditionally" public behavior, which is used to fix the balance, transports those same factors back to an era before the arrival of technology. The substitutive theory designates, as inescapably public, the kind of conduct that would have been available to the police in a much earlier age - if policing and privacy had existed in their modern senses, and if there had been a tradition, at that time, of balancing the two. The collage assembled in the phrase "traditional Fourth Amendment balance" freezes a number of moving targets and makes them all appear stable, with the exception of behavior that acts

government (in the form of either the constable or the magistrate) tended to enter the picture no earlier than the time of arrest, after private citizens had identified the suspected perpetrator.

William J. Stuntz, The Substantive Origins of Criminal Procedure, 105 Yale L.J. 393, 400-01 (1995) (footnotes omitted).

${ }^{66}$ See, e.g., John H. Langbein, The Origins of Adversary Criminal Trial 148 (2003) (discussing late seventeenth-century "reward statutes" by which the government sought to encourage "persons who apprehend and convict offenders who committed serious property crimes"; such encouragement was needed because "[t]he weak point in the received policing and prosecutorial practice was the neglect of the investigative functions, that is, seeking information when the facts of a crime were not fairly obvious.") (footnote omitted).

${ }^{67}$ On the English precursor to the police force established in the nineteenth century, see John Beattie, The First English Detectives: The Bow Street Runners and the Policing of London, 17501840 (2012).

${ }^{68}$ See Herbert Joyce, The History of the Post Office: From Its Establishment Down to 1836 (1893); Mark Brayshay, Royal Post-Horse Routes in England and Wales: The Evolution of the Network in the Later 16th and early 17th Century, 17 J. Hist. Geog. 373 (1991); J. Crofts, Packhorse, Waggon and Post: Land Carriage and Communications under the Tudors and Stuarts (1967); Howard Robinson, The British Post Office: A History, chaps. 2-3 (1948); Philip Beale, England's Mail (2005); Stewart \& Wolfe, Letterwriting in Renaissance England, 121-24; Ian Watt, The Rise of the Novel (1957), 187-96, esp. 189. 
on the world through the aid of others - whose migration from the public realm to the private one is halted on the ground that it destabilizes the traditional balance.

Even that summation understates the problems bedeviling this analysis, because the Fourth Amendment balance itself is no more stable than these other considerations. There was no Fourth Amendment balance until the Bill of Rights was ratified, and during the early nineteenth century, ideas about an acceptable basis for search or arrest underwent significant change. ${ }^{69}$ Privacy did not play a role in the Fourth Amendment calculus until the late nineteenth century. ${ }^{70}$ It was "security," not "privacy," that figured in the balance in the late 1700s and for a century afterwards. ${ }^{71}$ While it may now seem obvious that privacy is at the core of the security guarantee, this very obviousness is the result of a network of developments that changed social perceptions of privacy over a long period of time, in a process that changing views of the Fourth Amendment both reflected and influenced. According to the Supreme Court's modern jurisprudence, a primary venue for the Fourth Amendment's balancing act is the probable-cause requirement - "the best compromise that has been found for accommodating . . . opposing interests in safeguarding citizens from rash and unreasonable interferences with privacy and in seeking to give fair leeway for enforcing the law in the community's protection." 72 The requirement of "reasonable suspicion" also involves a balance of these interests, on a standard lower than probable cause. ${ }^{73}$ Activity that is not governed by either of these standards - that is, police conduct that does not involve a Fourth Amendment search - is not subject to any kind of

69 See, e.g., Barbara J. Shapiro, Beyond Reasonable Doubt and Probable Cause: Historical Perspectives on the Anglo-American Law of Evidence 141-42 (1991) (observing flux during the nineteenth century); Sterling v. Adams, 3 Day 411,418-19 (Conn. 1809) ("What shall be considered as probable cause, though a question of law, seems not to be very precisely defined."; "reasonable suspicion [is] probable cause"; "a very slight matter amounts to probable cause").

${ }^{70}$ Jed Rubenfeld, The End of Privacy, 61 Stan. L.R. 101, 115-16 (2008) (noting that Boyd v. United States, 116 U.S. 616 (1886), was the first Supreme Court decision "in which the terms 'privacy' and 'Fourth Amendment' both appear.").

${ }^{71}$ See id. at 119-32.

72 Michigan v. DeFillippo, 443 U.S. 31, 43-44 (1979) (internal punctuation and citations omitted).

${ }^{73}$ See, e.g., Florida v. Royer, 460 U.S. 491, 514-15 (1983) ("the reasonable suspicion standard . . . balanc[es] the amount of intrusion upon individual privacy against the . . . law enforcement interests that would be served by permitting such an intrusion on less than probable cause.") (citations omitted). 
balancing test. $^{74}$

The Fourth Amendment also establishes an overall equilibrium between law enforcement needs and individual privacy — an equilibrium produced by pooling the investigative activities that require probable cause, those that require reasonable suspicion, and those that require no basis at all, and comparing the conduct captured by these searches to the conduct that remains shielded from police activity. At any given time, the proportion between the crimes that can be effectively pursued and those that cannot will be a function of the prevailing methods of detection, the strategies adopted by criminals, the catalogue of prohibited acts, and the limits imposed by the Fourth Amendment. The methods of police and criminals are relatively dynamic, as compared to the law governing crime and criminal procedure. Thus the amount of crime that can be detected is bound to change as policing techniques and criminal predilections change, and so the overall equilibrium will fluctuate as the requirements of probable cause and reasonable suspicion remain stable. ${ }^{75}$ This seems to be the balance that Kerr has in mind when he speaks of a traditional Fourth Amendment balance. But whereas probable cause and reasonable suspicion both involve balancing tests set out by courts, pursuant to a constitutional guarantee, the equilibrium they help to produce is a byproduct of the tests, not an additional balancing test embraced by

74 See, e.g., Kyllo v. United States, 533 U.S. 27, 32-33 (2001) (police investigation “is not a search" unless "the government violates a subjective expectation of privacy that society recognizes as reasonable.”).

${ }^{75}$ It oversimplifies matters to say that these tests have remained stable. See Fabio Arcila, Jr., In the Trenches: Searches and the Misunderstood Common-Law History of Suspicion and Probable Cause, 10 U. Penn. J. Con. L. 1 (2007). However, the changes that Arcila identifies in the meaning of "probable cause" have not been restorative measures aimed at remedying a changing Fourth Amendment equilibrium, but if anything have further destabilized that equilibrium. See, e.g., id. at 44 ('[D]uring the Framers' era the phrase 'probable cause' could easily have been equated with a mere unreasoned 'hunch,' rather than with a reasoned basis for belief grounded in an articulable set of underlying facts."). For another view of the changing meaning of "probable cause," see Wesley MacNeil Oliver, The Modern History of Probable Cause, 78 Tenn. L. Rev. 377, 380 (2011) ("[P]robable cause, as we understand it today, is not the Framing-Era standard referred to in the Fourth Amendment. Probable cause as an evidentiary threshold effectively did not exist in criminal cases in the late eighteenth century. The origins of the modern standard lie neither with the Framers, nor in ancient doctrines that long preceded their work. Modern probable cause-a standard for criminal cases-was a by-product of the work of mid-nineteenth-century reformers."). The assumption that the probable-cause requirement has been stable across time and has served a uniform role, therefore, does not exaggerate any fluctuations in the general equilibrium, but instead minimizes them. 
any court or required by the text of the Constitution. ${ }^{76}$

To say that the traditional equilibrium needs to be maintained, and that substitutive conduct should therefore be blocked, mischaracterizes the place of the equilibrium in this scheme. According to the courts, an activity's status as private (or not) is a factor in determining whether probable cause or reasonable suspicion is required for a search, ${ }^{77}$ but under the restabilization approach, the activity's status may follow from the apprehension that too many crimes are going undetected, disturbing the equilibrium that used to obtain, so that we must respond by redefining privacy in narrower terms. Even if this solution were doctrinally permissible, we would need to know on what ground the old ("traditional") equilibrium could be designated as the legally proper one, rather than merely a more attractive one (because we were used to it, because it captured more criminals). Thus the problem is not ameliorated if in place of "traditional" we substitute "justified" or "proper," because in foregrounding normative considerations rather than ones supposedly based on custom, we simply make explicit the need to articulate the principle justifying the specific balance that is claimed as desirable.

It may well be that the third-party doctrine is a product of judges' pragmatic views about the need to catch criminals and the availability of incriminating evidence, and that as a practical matter, judges often treat the perception of growing crime rates as a justification for limiting the protection of privacy. ${ }^{78}$ If so, however, that pragmatic response is in tension with the courts' claims that both of

\footnotetext{
${ }^{76}$ Hence, even if it could be shown, in the context of American search and seizure law, that the current array of doctrinal exceptions emerged historically as the courts reacted to what they perceived as a changing equilibrium (see Kerr, supra note 58), this could serve as a descriptive account of the courts' pragmatism, but could not show that any of these revisions were normatively justified, because equilibrium-maintenance is not a constitutional norm. For an historically based challenge to Kerr's account, see Slobogin, supra note 57

${ }^{77}$ See, e.g., Fisher v. United States, 425 U.S. 391, 400 (1976) ("The Framers addressed the subject of personal privacy directly in the Fourth Amendment. They struck a balance so that when the State's reason to believe incriminating evidence will be found becomes sufficiently great, the invasion of privacy becomes justified and a warrant to search and seize will issue.").

${ }^{78}$ This appears to be general thrust of Kerr's more recent "equilibrium-adjustment" theory. See Kerr, supra note 58. See also Daniel Solove, Fourth Amendment Pragmatism, 51 Boston Coll. L. Rev. 1511, 1532-33 (2010) ("Professor Orin Kerr, who has provided the most robust defense of the third party doctrine, focuses his arguments on practical considerations about how the application of the Fourth Amendment will affect law enforcement investigations - not on the fact that people lack privacy in their records.") (footnote omitted).
} 
the doctrinally established Fourth Amendment balancing tests reflect policy decisions that have already been made, and are not open to revision, concerning the scope of privacy, the needs of law enforcement, and the proper balance between the two. ${ }^{79}$ If those claims about the probable-cause and reasonablesuspicion standards are correct, then as a doctrinal matter it cannot be persuasive, in responding to increases in criminal activity, to say that the Fourth Amendment equilibrium needs to be restored by redefining "privacy" to include acts, however and wherever conducted, that obviate the need to act visibly and openly.

If the needs of law enforcement could drive the definition of privacy in this fashion, the latter would be open to revision in either direction, depending on changes in crime patterns and policing methods. What if the crime rate rose because of an increase in certain kinds of non-substitutive conduct, long regarded as private under the Fourth Amendment? According to the theory of a traditional equilibrium, we could reverse the change by creating a test that characterizes some of that activity as only speciously private, so that we might eliminate the barriers that prevent police officers from monitoring it. Conversely, if criminals stopped using phones altogether, it would follow that this particular form of substitutive conduct should be regarded as private - because the needs of law enforcement no longer demand otherwise. Neither solution would be doctrinally defensible, because the Fourth Amendment's balancing tests require that policing and privacy be treated as equally significant. An increase in crime rates is a tragedy that requires an adequate response, but doctrinally there is no justification for responding by lowering the general level of privacy enjoyed by all citizens. Just as the traditional equilibrium does not correspond to any historically specifiable ratio of observable and concealable crime, it identifies no conceptual balance that any court has understood the Fourth Amendment to require.

The substitutive explanation also suffers from the problem that the third-party doctrine does not simply "restore" a technologically neutral status quo. Because information shared with third parties is deemed to be outside a reasonable expectation of privacy, the doctrine has the great virtue (from a law-enforcement

79 See, e.g., United States v. Place, 462 U.S. 696, 718 (1983) (“the Fourth Amendment ... has already performed the constitutional balance between police objectives and personal privacy.") (internal quotation marks and citation omitted) (Brennan, J, concurring); Zurcher v. Stanford Daily, 436 U.S. 547, 559 (1970) ("The Fourth Amendment has . . . struck the balance between privacy and public need, and there is no occasion or justification for a court to revise the Amendment and strike a new balance"). 
perspective) of opening up large quantities of information generated at a time when no one had any reason to conduct physical, real-time surveillance on the suspect. (The point is frequently dramatized in shows such as CSI, when the identification of a suspect rapidly leads to an array of earlier phone calls and bank transactions.) The doctrine does not simply give the police access to information they could otherwise have obtained (in a costlier fashion), because much of the information available from service providers would not otherwise have been obtainable at all. Far from restoring the status quo, the third-party doctrine puts the police in a much better position than they would be if the suspect had used no substitutive technology at all. ${ }^{80}$

Moreover, this approach would hardly fare any better even if we found the substitutive theory normatively persuasive. Say we agree that when open and visible behavior is replaced by concealed conduct, some principle explains why the latter ought not to be classified as private. In that case, what makes the conduct public is not the fact that it has been shared with a third party. The sharing is helpful, because it means that the police need not obtain the incriminating information from the suspect (who is legally permitted to refuse to divulge it), but instead can collect it from a source who probably has no reason to withhold it (and even if inclined to withhold it, may have no legal basis for contesting the demand). But the sharing, on this view, is an incidental convenience. The information is open to the police not because it was shared, but because it would be public in a world that did not afford these technological substitutions. If a someone invents a new form of technology, let us call it Syke, which allows him to contact his henchman without going through a third party, that technology has the same substitutive effect as a phone. If the submerging of public conduct is the feature that makes the action public, then Syke does not deserve to be called private any more than the phone does-but inconveniently for any law enforcement officer who hopes to detect the suspects' shenanigans, there is no third party ready to furnish details about the recipient or length of the conversation. Still, if the police could somehow come by that information, the suspects would have no right to keep them from acquiring it, because their behavior was already public.

${ }^{80}$ On this point, see also Murphy, supra note 57, at 1244 ("[T] $]$ he more that third-parties are involved or technology is deployed, ... the more likely it becomes that the criminal will be apprehended. ... [because] enlisting third-party assistance in crime tends to generate, rather than obfuscate, opportunities to get caught."). 
Indeed, if the key involves concealing conduct that would otherwise be observable, then the telephone and the mails do not begin to exhaust the catalogue of activities that should be characterized as public. If substitution is the key to the third-party doctrine, it is impossible to tell where to draw the line, such that some conduct, though characterizable as substitutive and hence as destabilizing a traditional Fourth Amendment balance, nevertheless ought to be deemed private. That is, there are no grounds for determining whether a certain act should be regarded as private - aside from declaring that it cannot conceivably substitute for open and visible conduct. But what conduct falls on the incontestably "private" side of that divide? Printing is a fifteenth-century technology that gives readers access, behind closed doors, to others' thoughts and ideas on a scale that would be impossible in a manuscript culture. Denizens of a former age would have been fortunate to have access to even a few documents in manuscript. ${ }^{81}$ Given the literacy rates that predominated in England and America before the nineteenth century, even having access to written materials would have been little help. Most people would have had to go outside to meet with the writer in person, or would have had to attend the theater or a public reading to hear the author's words. And if someone attended those events, others might have been able to observe her reactions to the words she heard. Today, the officer who is investigating a murder suspect, and who would like to know how much attention she paid to The Interpretation of Murder, will probably be unable to find any third party who can produce that information. But on the substitutive account, that detail does not keep the information from being public; it merely keeps the information from being readily accessible.

Again, consider the flush toilet - an invention of the late sixteenth century, ${ }^{82}$ and a device that is occasionally used to eliminate evidence. ${ }^{83}$ Indoor plumbing is another substitute for behavior that once would have involved open and visible conduct, at least to the extent that a person may be observed traveling to outdoor

\footnotetext{
${ }^{81}$ See, e.g., Harold Love, Scribal Publication in Seventeenth-Century England (1993).

${ }^{82}$ Sir John Harrington, A New Discourse of a Stale Subject, Called The Metamorphosis of Ajax (Elizabeth Story Donno ed. 1962) (1596). The final word in the title puns on the Elizabethan slang term "jakes," meaning a toilet (a point that the text underscores by rendering "Ajax" in two forms: "A Jax" and "A Jakes"). For a recent discussion, see Dolly Jørgensen, The Metamorphosis of Ajax, Jakes and Urban Sanitation, 3 Early English Stud. 1 (2010).

${ }^{83}$ See, e.g., DeMayo v. Nugent, 517 F.3d 11, 16 (1st Cir. 2008) (without "record evidence of any toilet flushing," police officers were not entitled to "infer" on the basis of other evidence that it had been flushed, and that contraband had been destroyed).
} 
facilities. Under the substitutive theory, an individual's use of the bathroom is no more private than her use of the phone - though it may be inconvenient for the police (if it would aid in an investigation) that no one recorded the time or length of the use. Of course, phone calls and bank accounts figure more often in investigations than reading matter and visits to the bathroom, but the latter examples cannot be excluded categorically simply because they are less likely to be associated with criminal activity. The important consideration is whether the conduct is deemed "public" under the Fourth Amendment, even if only rarely associated with crime. Once recognized as a means of shielding behavior that would otherwise be observable, many seemingly private technologies become public. $^{84}$

As to the unavailability of information in the examples above, consider these hypotheticals. A publisher, eager to help customers find "more like this," equips books with a device that clocks a reader's progress, page by page, and that measures her temperature, pulse, and brain activity as she reads. Readers may submit that information to the publisher or keep it to themselves. A new diet fad involves the use of "smart toilets" that keep track of what gets flushed and when. Users may simply let the data accumulate or submit it to the diet promoter for feedback. Now imagine a consumer who does not pass this information along to anyone else. Under the substitutive theory, this information is inherently public and merely lacks a conduit that would allow others to see it. If the police could obtain this information with a device from the manufacturer that could retrieve that data from afar, then it is not clear, on the substitutive theory, why citizens ought to be able to keep them from using it.

Yet another reason for doubting the force of the substitutive explanation is that the third-party doctrine has not been limited to information that would be observable if the suspect had not resorted to substitution. For example, along with phone numbers, the doctrine also provides access to the time of the call and its duration, whereas if the suspect instead traveled to see her accomplice, this same information (how long did the suspects talk, what time did they talk) could rarely

${ }^{84}$ Indeed, it is doubtful whether even houses, which may also be seen as technological devices, should form part of the already extant landscape at the "hypothetical Year Zero" in Kerr's more recent rendition of the argument. Kerr, supra note 58, at 483 (noting that police would have only a few options available at Year Zero, including "knock[ing] on the door of a suspect's home and ask[ing] to speak with him," and "forcibly search[ing] a suspect's 'houses, papers, and effects") (footnote omitted). 
be specified with similar precision - and in some instances, that precision is vital in establishing probable cause. These are details that might remain inaccessible if the conversation were conducted behind closed doors. More generally, if the open and visible conduct is the suspect's journey at a certain time to a certain location, it is apparent that records from service providers yield much more information than could have been learned by tailing the suspect-yet no court has taken the view that these other details are not available to the police. There may be problems with the proposition that the bank records are analogous to documents left in plain view, but this explanation at least has the virtue of accounting for the doctrine as courts have routinely applied it.

In short, the substitutive theory proves too little and too much. It proves too little because it supplies no reason for concluding that whatever would include a publicly visible aspect, in a world without technological substitution, ought to be regarded as public. It appeals to "tradition," using that term to designate an equilibrium that is assumed without argument to be desirable and that finds no historical basis for its understanding of policing needs, or privacy, or the amount of surveillable conduct that their balance produces. That certain actions, now conducted behind closed doors, would once have had to take place in the open, does not explain why those actions should be treated as public. The disruption of a notional equilibrium, under which a certain ratio of criminal activity is detectable, cannot provide a justification unless we are given a reason for believing that we know how to identify the proper equilibrium, according to a legal standard. On the other hand, the theory proves too much because if we treat substitutive actions as public, then the stripping away of Fourth Amendment protection has nothing to do with the third party who had access to the information, but instead depends on whether the suspect resorted to a technological shortcut that was unavailable in a previous era. In consequence, the category of public information would include much more than the third-party doctrine has allowed so far. Yet the doctrine has always turned on the exposure of information to a third party, not the removal of information from public view. If such exposure were treated as merely incidental to a public/private distinction that precedes the exposure, the doctrine would undergo a remarkable expansion.

The argument from ex ante clarity adds little justificatory force to the substitutive argument. As to the data typically associated with the third-party doctrine-records of phone calls, bank accounts, and the like-the courts could create just as much certainty by ruling that individuals maintain a reasonable 
expectation of privacy in these records. ${ }^{85}$ Under the doctrine as it currently stands, police officers know that they may go to the phone company, the bank, and similar service providers to request these records. If the doctrine did not allow for those requests, the police would know in advance that reasonable suspicion or, more likely, probable cause would be required. ${ }^{86}$ With respect to these kinds of records, "Fourth Amendment protection for [the] information" would just as closely match the "Fourth Amendment protection for the environment in which it is stored" 87 if the courts refused to entertain the third-party doctrine. The places where those records are normally found (namely, the service providers' offices) are not murky environments in need of clarification, but are clearly identifiable in advance as open or not to warrantless inspection.

Indeed, it would be just as plausible to assert that the doctrine creates confusion rather than certainty. After all, some environments (e.g., a stolen briefcase, a backpack searched by an overreaching officer who had authority only to detain the suspect ${ }^{88}$ might mix materials that are open to police scrutiny, by virtue of having been shared with others, with other materials that are not open to scrutiny, so that the documents' location does not resolve the question of their

${ }^{85}$ For similar analyses, see Stephen E. Henderson, The Timely Demise of the Fourth Amendment Third Party Doctrine, 96 Iowa L. Rev. Bull. 39, 44 (2011) (finding that the clarity afforded by the third-party doctrine in Kerr's account has "little to commend it" and adding, "Nor would it be less clear to have the opposite default: Police cannot access any record information without probable cause."); Murphy, supra note 57, at 1245 ("[I]f the primary aim is clarity, then I would instead vote in favor of a very clear rule . . that simply prohibits all third-party investigation without a warrant or probable cause"). Murphy also notes that the probable-cause requirement does not set "a particularly high standard to meet," and that in Smith, supra note 3, the police could have met that standard. Id. at 1244 .

${ }^{86}$ For an argument differentiating the contexts in which one or the other of these standards would apply to personal records, see Christopher Slobogin, Transaction Surveillance by the Government, 75 Miss. L.J. 139, 1667-82 (2005). For an argument that even material left in plain view should sometimes require reasonable suspicion, and should not be open to random search, see R. v. Patrick, [2009] 1 S.C.R. 579, at para. 77 (Can.) ("[P]ersonal information emanating from the home, which has been transformed into household waste and put out for disposal, is entitled to protection from indiscriminate state intrusion. ... Before the state can rummage through the personal information from this ultimate zone of privacy, there should be, at the very least, a reasonable suspicion that a crime has been or is likely to be committed.") (Abella, J., concurring).

${ }^{87}$ Supra note 53.

${ }^{88}$ See, e.g., United States v. Payner, 447 U.S. 727 (1980) (briefcase); United States v. Humphrey, 2007 WL 1341356 (W.D. Tenn. 2007) (backpack). 
status. ${ }^{89}$ In such a case, the documents classified as "public" on third-party grounds would presumably be immune from exclusion, while the others would be suppressed. Where the police have a warrant, courts have generally allowed them to see those materials that fall outside the warrant, if it would otherwise be impossible to act on the warrant. ${ }^{90}$ But when a search proceeds without probable cause, it is hard to see why the police should be permitted to inspect all of the documents in order to determine which ones, on their face, bear the hallmarks of coming from a third party.

Finally, it may be noted that in supporting the argument for ex ante clarity, Kerr considers the example of an opened letter found open on a suspect's deskan example that does not turn on the third-party doctrine. ${ }^{91}$ If the police have access to a suspect's home, so that a letter sitting on a desk is within their legal ken, then either they have a warrant, supported by probable cause, or else a warrant is not required because they have received consent to enter or are acting in exigent circumstances. ${ }^{92}$ In any of these scenarios, the police may see whatever is permitted according to "the usual rules of home searches," 93 but in none of

${ }^{89}$ Moreover, in some instances, it may not even be self-evident which materials fall into which category. A document that was shown to a third party, and was then filed away, might no longer command a reasonable expectation of privacy, but in that case the document's status turns on details that may be unknown to the police at the time of the search.

${ }^{90}$ See, e.g., Anderson v. Maryland, 427 U.S. 463, 482 n.11 (1976) ("In searches for papers, it is certain that some innocuous documents will be examined, at least cursorily, in order to determine whether they are, in fact, among those papers authorized to be seized."); United States v. Ochs, 595 F.2d 1247, 1257 n.8 (2d Cir. 1979) ("courts . . . have upheld without much discussion the seizure of documents during an otherwise valid search as in 'plain view' notwithstanding the fact that some perusal, generally fairly brief, of the documents was clearly necessary in order for the police to perceive the relevance of the document to crime."); United States v. Crouch, 648 F.2d 932, 933 (4th Cir. 1981) (where police officers were "legally on the premises pursuant to a search warrant," they "acted within the scope of the search warrant in removing . . . letters from their envelopes to search for the chemicals and paraphernalia named in the warrant").

${ }^{91}$ Kerr, supra note 49, at 582 ("Consider a letter that arrives in the mail, is opened, and sits on the recipient's desk at home in a stack of other letters and other papers. The third-party doctrine dictates that the letter is treated just like all the other papers on the desk.").

92 See Soldal v. Cook County, Ill. 506 U.S. 56, 65-66 (1992) ("police officers [may] lawfully enter a house, by either complying with the warrant requirement or satisfying one of its recognized exceptions - e.g., through a valid consent or a showing of exigent circumstances."); Callahan v. Millard County, 494 F.3d 891 (10th Cir. 2007) ("[T]he Supreme Court . . . [has] clearly established that to allow police entry into a home, the only two exceptions to the warrant requirement are consent and exigent circumstances.").

${ }^{93}$ Kerr, supra note 49, at 582. 
these scenarios can it be said that the third-party doctrine is the mechanism rendering the letter available. ${ }^{94}$ Assuming, for example, that the police are legally present under a probable-cause exception, there would be no difference between a letter received through the mail, tucked back into an opened envelope, and a note from the suspect to herself, tucked in an unsealed envelope. In this situation, both would be unavailable, and conversely both would be available if the letter were unfolded and visible at the top of a pile (in plain view). The justificatory strength of the argument from ex ante clarity, then, is minimal. However, this is not to say that the doctrine fails to instruct those who would look to it for guidance. Just as the substitutive explanation provides deep insight into the doctrine's effects, if not its rationale, the same may be said for the notice function.

\section{III.The Novel AND THE THIRd PERSON}

To students of literary history, the suggestion that the public/private divide is open to manipulation in the service of policing will have a familiar ring. If unconvincing on normative grounds, the substitutive account becomes far more persuasive when seen as delineating a Foucaultian view of disciplined subjects who understand themselves to be constantly under surveillance, and who have internalized this expectation. ${ }^{95}$ Inspired by Foucault, numerous accounts of

${ }^{94}$ Kerr supports the "open letter" hypothetical by reference to United States v. Villarreal, 963 F.2d 770, 774 (5th Cir. 1992). That case did not involve a home search, nor did it present a setting in which there was ambiguity about the applicable Fourth Amendment rules. In Villareal, police found contraband through a warrantless search of a package that they had opened in transit to the defendant. In affirming the district court's suppression of the evidence, the court of appeals noted that "senders and addressees of packages or other closed containers can reasonably expect that the government will not open them [in transit]," but did not address the legality of examining the contents after delivery. Id. Doubtless an opened letter could be available to police officers who had a legal basis for being present in the home and conducting a search — but that basis would not be afforded by the third-party doctrine.

95 "Internalization" in this sense is drawn not from economics but from the intellectual contexts that gave rise to the term's use in economics. In social theory and psychology, internalization describes a process of self-policing in which persons turn an "inspecting gaze" on themselves, "interiorising" the gaze so as to become their "own overseer[s]." Michel Foucault, The Eye of Power, in Michel Foucault, Power/Knowledge: Selected Interviews and Other Writings, 19721977, at 146, 155 (Colin Gordon ed. 1980). The term seems to have gained currency in the psychological sense in the 1880 s, and does not appear to have been adopted by economists until the late 1950s. See, e.g., Edwin Paxton Hood, The Day, the Book, and the Teacher 38 (1880) ("A man's soul is never so open to universal influences as in a great company. . . Alone, he internalizes more; but then the value of that depends on whether he have anything to internalize, 
surveillance as a feature of modern culture have looked to literary texts - and particularly the novel - to show how privacy, rather than emerging from a distinct set of values, is a contingent product of the policing process (among other social developments). Indeed, these arguments tend to treat novels as complicit in the work of policing and the production of privacy. In these accounts, the concept of policing takes its origin from the investigation of illegal conduct, but is typically explored in relation to conduct regulated by the laws of the social order-conduct assessed on the basis of its adherence to, or deviation from, cultural imperatives expressed through everyday modes of social interaction, and particularly through bureaucratically produced forms that strive to make people knowable and accountable.

According to Foucault, documents that present themselves as recording devices - census forms, mortgage applications, medical diagnoses, welfare files, professional licenses - function as apparatuses by which the applicant, or subject, or patient learns how to render herself legible and hence may be impelled to internalize the demand for legibility that the form extends. ${ }^{96}$ One of the primary tenets of this line of argument is that insofar as any area may be characterized as private, and is therefore ostensibly shielded from social or bureaucratic demands for legibility and from concern about their possible enforcement, it is only because that characterization suits the needs of the social order that has produced this distinction. More precisely, on this account no area of life can safely be assumed to be inviolably protected from the scrutiny of social policing, because conduct may always be reclassified as open to such scrutiny if that would advance the policing effort. This line of argument typically treats the reclassification itself as a standard ploy, by which the term "private" serves to lure people into believing that they have a safe refuge, so that they may be compelled unwittingly to reveal the truth about themselves when the indulgence is withdrawn.

or, if so, what it is that he internalizes"); Vincent Ostrom, Review: Tools for Decision-Making in Resource Planning, 19 Pub. Admin. Rev. 114, 118 (1959) ("By changing the scale of the management unit, external economies or spillover effects can be 'internalized"').

96 See, e.g., James Boyle, Foucault in Cyberspace: Surveillance, Sovereignty, and Hardwired Censors, 66 U. Cin. L. Rev. 177, 186-88 (1997-1998); Paulo Vaz \& Fernanda Bruno, Types of Self-Surveillance: From Abnormality to Individuals “at Risk", 1 Surveillance \& Soc'y 272 (2003); David Murikami Wood, Beyond the Panopticon? Foucault and Surveillance Studies, in Space, Knowledge, and Power: Foucault and Geography 245-64 (Jeremy W. Crampton \& Stuart Eldon eds., 2007). 
The analogy between criminal law enforcement and the enforcement of social norms finds its origin in Bentham's proposal, in 1791, for a Panopticon, a prison arranged in concentric rings, with the guards in a central tower and the prisoners confined in cells distributed around the periphery. ${ }^{97}$ By making the prisoners visible from the tower at all times, but leaving them unable to tell whether they were being watched, the arrangement would ensure that they would always behave as if they were being observed. ${ }^{98}$ For Foucault, the Panopticon ("allseeing") provides a model for techniques of social control that create in the populace a "state of conscious and permanent visibility." 99 Literary critical interest in this model has focused particularly on novelistic techniques that open the characters to the reader's observation. Two features are especially notable for their ability to produce this effect for the reader: omniscient narration, which gives the reader a perspective on the events within the fictional world that the characters can never achieve, and free indirect discourse, which renders the characters' thoughts an open book. The contours and limits of the analogy are readily discernible: in the Panopticon, prisoners may be partly visible to each other, but they are always completely open to scrutiny by those in control of the prison. The fictional analogue is the third-person omniscient narrative, where the characters' limited ability to understand each other pales by contrast with the narrator's all-seeing perspective. On the other hand, whereas prisoners might try to rebel or to resist the guards' authority, it is not open to novelistic characters to disobey the narrator, or even (except in highly self-conscious fiction) to show that they are aware of the narrator's scrutiny. ${ }^{100}$ They have nothing to hide from the narrator precisely because the narrator describes what the author created, and so by definition they cannot exceed the narrator's knowledge about them. ${ }^{101}$

${ }^{97}$ Jeremy Bentham, Panopticon: Or, the Inspection-House 4-5 (1791).

${ }^{98}$ Michel Foucault, Discipline and Punish 202 (Alan Sheridan trans. 1977) (" $[I] n$ the peripheric ring, one is totally seen, without ever seeing; in the central tower, one sees everything without ever being seen.").

${ }^{99}$ Id. at 201.

${ }^{100}$ On this distinction between fictional characters and prisoners, see, e.g., Dorrit Cohn, Optics and Power in the Novel, 26 New Literary Hist. 3, 15 (1995); Jan Alber \& Frank Lauterbach, Introduction, in Stones of Law, Bricks of Shame: Narrating Imprisonment in the Victorian Age 3, 10 (Alber \& Lauterbach eds., 2009). For examples in which the characters resist or rebel against the narrator, see, e.g., Flann O’Brien (pseud. of Brian O'Nolan), At Swim-Two-brids (1939); John Fowles, Mantissa (1982).

${ }^{101}$ Whether they also exceed the reader's knowledge about them is a different question. Since the later nineteenth century, many novelists have described the work of creation as involving richly imagined details about their characters that never made into the novel, but that were necessary in 
D.A. Miller offers a useful analysis of this dynamic in The Novel and the Police. ${ }^{102}$ Miller's account has been highly influential among literary critics, and, unusually for scholarship that examines social discipline, his discussion attends to the significance of policing not only as a kind of internalized law enforcement, exemplified by self-discipline, but also in the sense more familiar to Fourth Amendment scholars. ${ }^{103}$ Though unusual, his work is not unique in this respect. John Bender, in Imagining the Penitentiary, similarly takes up questions of narrative perspective and the control of criminal behavior, discussing surveillance in relation to eighteenth-century English fiction, though focusing on imprisonment and public executions rather than on the investigation of crime. ${ }^{104}$ Lisa Rodensky, in The Crime in Mind, examines narrative modes in Victorian fiction and the contemporaneous development of legal thought about culpability. ${ }^{105}$ In particular, her account shows how the narrative refusal to provide access to characters' minds may hint at the limits of a model premised on surveillance and internalization. ${ }^{106}$ In the work of these literary scholars and

order to develop the characters in the first place. Presumably some of those details might be inferred from the information that is given in the text, but others could be known only to the author. George Eliot, for example, drew herself a map of the characters' estates in Middlemarch, and Sinclair Lewis made a highly detailed set of maps of Zenith, the setting for Babbitt. George Eliot, Quarry for Middlemarch (Anna Theresa Kitchell ed., 1950); Helen Batchelor, A Sinclair Lewis Portfolio of Maps: Zenith to Winnemac, 32 Mod. Language Q. 401 (1971).

${ }^{102}$ Miller, supra note 6. David Sklansky has also noted the implications of Miller's research in relation to Fourth Amendment jurisprudence; see Sklansky, supra note 16. In a recent essay on "The Wire," Ryan Miller uses Miller's analysis of omniscient narration to explain how the television show "dramatizes the effects of power while simultaneously denying its own power as a literary entity, to regulate the behavior of its viewers." Ryan Miller, The Narrative Production of "Real Police," in C.W. Marshall, ed. The Wire: Urban Decay and American Television 64 2009).

${ }^{103}$ For other discussions, see supra note 17.

104 John Bender, Imagining the Penitentiary: Fiction and the Architecture of Mind in EighteenthCentury England (1987). Bender returns to these issues in two later essays, now reprinted in book form. See Bender, Prison Reform and the Sentence of Narration in The Vicar of Wakefield, in John Bender, Ends of Enlightenment 133-53 (2012), and Impersonal Violence: The Penetrating Gaze and the Field of Narration in Caleb Williams, in id. at 154-179.

${ }^{105}$ Lisa Rodensky, The Crime in Mind: Criminal Responsibility and the Victorian Novel (2003).

${ }^{106}$ See, e.g., id. at 115-16 (discussing the tonal shifts by which George Eliot's narrator, in Adam Bede, declines to pronounce definitely on a character's thoughts, after having "roamed quite freely" in his mind, and showing how Eliot's handling of this problem, by emphasizing "the difficulty of understanding the 'agents' of minds, even if one had the access of a third person narrator," tracks James Fitzjames Stephen's treatment in A General View of the Criminal Law (1863)). 
others, ${ }^{107}$ questions involving what readers are allowed to know about characters' minds, and how the conditions of access might influence the reader's own sense of vulnerability to such access by others, are framed in relation to legal developments, most often in relation to legal institutions and processes. The discussion here, building on this work, focuses more specifically on legal doctrine.

Miller's analysis is particularly helpful because its treatment of surveillance extends to the work of gathering evidence, in this case illustrated by the efforts of Inspector Bucket in Dickens's Bleak House. ${ }^{108}$ Miller highlights the same sense of contingency that accompanies the turn to a substitutive explanation in Kerr's account. As noted earlier, the Fourth Amendment's traditional equilibrium has no doctrinal mooring but is instead a product of the balancing tests that courts have extracted from the text of the Fourth Amendment. The theory of a traditional equilibrium turns on two premises: first, we must be able to identify (at least roughly) the ratio, in a world without substitutive technology, between activities that are observable on a warrantless basis, and those for which a warrant would be required, and second, we must agree as a doctrinal matter that when the ratio gets too warped, the definition of privacy may be revised to bring the proportions back into their earlier state. Miller targets a similar idea when he writes that in Bleak House, the police are generally portrayed as confined to a limited sphere, and are allowed to move beyond those boundaries only when "warranted by exceptional circumstances." 109 However, Miller adds, Bleak House refrains from portraying the police as a vast, omnipresent, aggressively investigatory fleet, and instead shows the reader only Inspector Bucket; in doing so, the novel opts for a "comforting principle of localization," ostentatiously restricting its portrayal to a single member of the detective police, as a means of raising "the fear-inspiring prospect of the possible suspension of this principle." ${ }^{\prime 10}$ We see only one police officer, but he hints at the presence of the many who could be shown if circumstances demanded it. Moreover, the officer we are shown proves to be capable of appearing in unlikely places, and covering large distances rapidly, as if

${ }^{107}$ For other examples, see Jonathan H. Grossman, The Art of Alibi: English Law Courts and the Novel (2002); and Jan-Melissa Schramm, Testimony and Advocacy in Victorian Law, Literature, and Theology (2004), both of which discuss narration in the context of legal developments affecting criminal defendants' eligibility for representation by counsel.

${ }^{108}$ Charles Dickens, Bleak House (Patricia Ingham ed., 2011) (1851).

${ }^{109}$ Miller, supra note 6, at 78.

${ }^{110}$ Id. 
endowed with "superhuman and ... magical" abilities. ${ }^{111}$

The ultimate effect of this portrayal of the police, Miller explains, is to "establish a radical uncertainty about the nature of private, familiar space." "112 If the third-party doctrine maintains technological neutrality by blocking the substitution effects of those who would perform public acts in private, in Bleak House the police achieve something similar: "Bucket maintains the difference between public . . . and private . . . spheres as a part of a successful attempt to neutralize it." 113 In the novel, what appears to be private is also susceptible to reclassification as public conduct when it serves policing needs. As it turns out, Bucket's reason for offering to observe the distinction between the two spheres depends on the prototypical incarnation of the third-party doctrine-the undercover officer or the untrustworthy friend. To track down Mr. George (suspected of murdering the lawyer, Tulkinghorn), Bucket decides to ingratiate himself with the Bagnet family, whom he believes to be harboring the suspect. Rather than donning a disguise, he simply pays the Bagnets a friendly visit, explaining that he is not conducting official business and should be treated with no more ceremony than any other guest. Claiming to have happened along by chance, he utters various "blandishments" that "entirely [win] the family heart," and get him invited inside. ${ }^{114}$ Soon Mrs. Bagnet is "waiting upon him hospitably," and after further pleasant chit-chat, even Mr. George, "who testified no great emotions of pleasure on [Bucket's] entrance," proves, "in spite of himself," to be pleased with Bucket's courtesies. ${ }^{115}$ Seemingly acting in a private capacity, Bucket exploits the Bagnets' hospitality so that (as Miller describes it) he may be "welcomed into the ... household, where, at the proper moment-no longer as a new friend of the family but now a public official- he can arrest their friend and guest Mr. George." 116 This visitor, a friend at one moment and a police officer the next, conveniently personifies a doctrine premised on the view that what has been shared with another should be regarded, by the same token, as having been shared with the police.

\footnotetext{
${ }^{111}$ Miller, supra note 6, at 79.

112 Id. at 80. See also Audrey Jaffe, Vanishing Points: Dickens, Narrative, and the Subject of Omniscience 9 (1991) ("[I]t is precisely by invading privacy that omniscience defines the boundaries of privacy for nineteenth-century readers.").

${ }^{113}$ Miller, supra note 6, at 79.

${ }^{114}$ Dickens, supra note 108, at 593.

115 Id. at 595

${ }^{116}$ Miller, supra note 6, at 80 .
} 
Few modern courts would cavil at these tactics. Bucket enters the Bagnets' home with their consent and without concealing his identity, and he conducts only the most casual of searches, finding Mr. George already present and having no need to search for other evidence - though Bucket does establish, with a few sly questions, that there is no route of escape except through the front door. ${ }^{117}$ His finesse in getting "his friendly hold" over Mr. George and taking the latter into his "custody" might seem like nothing more than a legitimate and well-executed investigation. ${ }^{118}$ If Bucket's cagey management of the Bagnets' hospitality were Miller's primary instance of novelistic policing, the subject would hardly be regarded as provocative or even worthy of much attention.

Miller's more controversial argument is that Bucket achieves, within the plot of Bleak House, the same effect that many Victorian novels produce tacitly on their readers, without needing to portray any police officers. In this account, just as the novel helps to limn and conceptualize a private sphere that readers perceive as placing a limit on public, disciplinary power, the narrative modes that suffuse the genre serve to subject the characters to the same forms of control and supervision, making readers see that there is no realm that evades the policing power, no way to escape its all-pervading gaze. In Trollope's Barchester Towers, for example, where the police "are literally nowhere to be found," 119 it turns out that even happenstance social misunderstandings correct themselves, so that "to negate the police means already to have subsumed them." ${ }^{120}$ In this world, "a subject is entitled to freedom only on condition that he or she tactfully internalizes as 'self-control' what would otherwise, to achieve the same results, have to appear as massive institutional intervention." "121 And the police need not be represented as the wielders of such control-not even through the solitary figure of an Inspector Bucket-because this task is modeled by means of the "novelist's

\footnotetext{
${ }^{117} \mathrm{Mr}$. George recognizes Bucket as soon as the latter appears, declaring "Why, it's Bucket!" and the visitor is declared to be "not unwelcome." Dickens, supra note 108, at 593. Bucket's cagey observation about the Bagnets' "very nice back yard" and his casual query as to whether there is "[a]ny way out of that yard" would probably be treated as reasonable and minimally intrusive, and incapable of raising Fourth Amendment concerns. See, e.g., United States v. Burton, 441 F.3d 509, 511 (7th Cir. 2006).

${ }^{118}$ Dickens, supra note 108, at 596.

${ }^{119}$ Miller, supra note 6, at 107.

${ }^{120}$ Id. at 111.

${ }^{121}$ Id. at $111-12$.
} 
minute and sustained moral appraisal of [the characters],"122 a judgment delivered from "the position of the omniscient Victorian novelist, who must know whether his charges be true or false." 123 We can never apprehend any of the characters and become aware of their merits or demerits except through the narrative lens that thereby reminds us, if only implicitly, of the means that facilitate this access. Miller notes the potentially "paranoid" tenor of this argument, as have many of his critics. ${ }^{124}$

Whatever might be said about the paranoia underwriting this account, the term has aptly been applied to the effects of the third-party doctrine, ${ }^{125}$ and one effect of Kerr's argument - though perhaps an inadvertent one-is to show why the term applies so well. In the substitutive theory, the third-party doctrine functions in much the same fashion as the novelist's narrative tactics in Miller's account: the doctrine's efficacy is inextricably bound up with the seemingly private nature of the activities it governs. We tend to regard our use of the phone or the bank as private even if we know that, from a Fourth Amendment perspective, we cannot reasonably expect them to be treated as private. Someone who could not resort to technological substitution and who was protective of her privacy, whether a criminal or not, would consciously take steps to make her conduct less noticeable to others (her efforts might fail, but the significant point is that she would be attentive to her conduct's public status). The seemingly private nature of most substitutive technologies makes the person who uses them less likely to take similarly wary steps, and more likely to appear paranoid if she does use such measures. ${ }^{126}$ If people truly regarded dialing the telephone and making a journey

\footnotetext{
${ }^{122}$ Id. at 134.

${ }^{123}$ Id. at 135.

${ }^{124}$ Miller, supra note 6, at 107. For criticism of Miller, see, e.g., Simon Joyce, Resisting Arrest/Arresting Resistance: Crime Fiction, Cultural Studies, and the "Turn to History", 37 Criticism 309, 326 (1995). For a helpful discussion of the charge of "paranoia," in this context, see Rita Felski, Suspicious Minds, 32 Poetics Today 215 (2011).

${ }^{125}$ Elizabeth Paton-Simpson, Privacy and the Reasonable Paranoid: The Protection of Privacy in Public Places, 50 U. Toronto L.J. 305 (2000).

${ }^{126}$ See id. at 305-06 (describing an "entirely reasonable" character named Prudence who "could be accused be being paranoid" because she "refuses to chat with friends over the telephone," "develops all her photographs herself," and takes various other steps to "avoid being judged to have given implied consent to surveillance [of her conduct]"). See also Scott E. Sundby, "Everyman"'s Fourth Amendment: Privacy or Mutual Trust Between Government and Citizen?, 94 Colum. L. Rev. 1751, 1789-90 (1994) ("To maintain privacy, one must not write any checks nor make any phone calls. It would be unwise to engage in conversation with any other person, or to walk, even on private property, outside one's house... The wise individual might also consider
} 
as similarly "public," we would probably see less substitutive conduct in general, and more furtiveness surrounding it - and hence less grist for the third-party doctrine. In focusing our attention on the substitutive nature of this conduct (rather than merely saying that the information was shared, and is therefore public), Kerr usefully highlights its ambiguous nature. People engage in this limited kind of information-sharing not (for example) because they wish to tell the phone company whom they called, but because this conduct does not seem like information-sharing at all. The substitutive label helpfully captures this sense of seemingly private conduct that, by virtue of its functional role as a replacement for public conduct, thereby merits the legal characterization of "public" and remains open to warrantless scrutiny. Just as Bucket presents himself as a private friend so that he may later reassert his status as an officer, the third-party doctrine also thrives on this ambiguity.

Thus if the "substitutive" label does little to explain why certain activities should be deemed public, it helps to show the effect of deeming them to be public. As noted earlier, two kinds of substitution are at work in these cases: ostensibly private conduct is treated as functionally public and is reclassified on that ground, and the police, who might otherwise have to make themselves open to observation by the suspect, need not undertake risky stakeout or tailing operations, but may instead obtain information through measures that are almost certain to remain unobservable. The third-party doctrine teaches that those whose activities are open to observation-namely, everyone whose activities produce the kinds of records that the doctrine captures-should constantly regard themselves as open to surveillance. If we say, with the courts, that these individuals simply have no "reasonable expectation of privacy" in the records, we state a doctrinal truth without explaining why the doctrine functions so effectively. By saying instead that it applies to substitutive conduct, we identify the feature that gives the doctrine so much power: its ability to relabel conduct that seemed private at the time, and to make the details available to the police through means that do not require any visible effort on their part (that is, any effort that the suspect might

purchasing anti-aerial spying devices if available .... Upon retiring inside, be sure to pull the shades together tightly so that no crack exists and to converse only in quiet tones. When discarding letters or other delicate materials, do so only after a thorough shredding of the documents."); Aya Gruber, Garbage Pails and Puppy Dog Tails: Is that what Katz is Made of?, 41 U.C. Davis L. Rev. 781, 799 (2008) ("the reasonably private person must be a super-paranoid individual who has walled in his house, speaks in code, buries the trash in the backyard, and keeps money under the mattress") (citing Sundby, supra). 
notice, and that might tip him off). Inherently public conduct is not substitutive, and few would make the mistake of considering it private. But when conduct is open to recategorization that may strip it of any Fourth Amendment protection, a term that describes this process goes a long way towards explaining the source of the doctrine's power. The police might seem to possess the same "superhuman" and "magical" powers that Bucket appears to displays in Bleak House.

If Bucket personifies the third-party doctrine, he thereby also represents its prototypical form in a narrotological sense. He may seem omnipresent in Bleak House, but by virtue of being embodied, his perspective is focalized and situated (like that of the reasonable officer in the usual analysis of probable cause) rather than being omniscient. ${ }^{127}$ Recall the "public access" and "false friend" examples discussed earlier: in these archetypal versions, we do not need the third-party doctrine to justify the admission of evidence. When officers collect evidence in either of these scenarios, and have not acted illegally in order to gain a position of trust or observation, the information they obtain is within their personal knowledge, and is admissible on that basis. Indeed, Miller implicitly contrasts Bucket's role, as a specifiable figure whose perspective is necessarily limited to what he can see, against the role of the omniscient narrator, who faces no such constraint and who therefore provides the better analogue for Bentham's Panopticon: "Balzac's omniscient narration assumes a fully panoptic view of the world it places under surveillance. Nothing worth knowing escapes its notation, and its complete knowledge includes the knowledge that he is always right." This could not be said of Bucket, because no matter how rapidly he can travel, he can never have similarly complete knowledge about the other characters, who after all are not his own creations.

The kind of "total knowledge" imagined in this description recalls another aspect of the substitutive theory, implicit in Kerr's account. One of the theory's premises involves the claim that substitutive behavior replaces conduct that would have been open and visible, so that an officer who had reason to be interested in the suspect would at least have had the opportunity to tail him and to find out where the trail led. But as we have seen, one reason why third-party records are so valuable is that they do not come into being at the moment when the police have identified a suspect. Instead, they provide details about a suspect-to-be, a person-

\footnotetext{
${ }^{127}$ See supra note 36.

${ }^{128}$ Miller, supra note 6, at 23.
} 
not-yet-of-interest - details that may have been recorded months or years before the investigators' attention turned to this particular suspect. Thus the records may put the police in a much better position than surveillance could possibly achieve - and at almost no cost, because the time, expense, and potential dangers of tailing the suspect are eliminated.

Here, again, the analogy with narrative perspective gains force. Novelists generally do not restrict the reader's knowledge about a character's conduct to a period that begins when the character does something that might incite the interest, curiosity, or suspicion of others in the fictional world. Even in a narrative focalized through a single figure's perspective, the story may begin long before other characters have any reason to scrutinize the aspects of the protagonist's behavior that are presented to the reader. Moreover, regardless of when the story begins, the author might use flashbacks or other techniques to describe earlier events. The reader is shown much more of the protagonist's conduct than any other character could possibly see. There is nothing, of course, to prevent a writer from matching the onset of narrative attention with a criminal action, or with something like reasonable suspicion - and some mystery writers make a point of structuring their stories in exactly that fashion. ${ }^{129}$ But that option hardly defines the limits of fictional possibility, and our experiences as readers of fiction give us much more exposure to stories that are not structured in this way. In describing thoughts and actions that are available only to the reader, narrators can start whenever they like - though it is up to us to determine the significance of that information. In the same way-but with the benefit of hindsight and the determination to find significance everywhere - the third-party doctrine eradicates the restriction that would limit investigators to those details postdating the onset of reasonable suspicion. The result is to endow the police with the ability to find potentially incriminating meaning in events where none might have been discernible if they had been observed in real time.

The panopitic analogy takes on additional force in relation to the third-party doctrine because, as analyzed by Foucault, the analogy illuminates not only the contingency of the public/private divide, but also the argument from ex ante clarity, which addresses the means by which these disciplinary efforts are achieved. It was argued above that if we look to the documents typically associated with the third-party doctrine - records held by a service provider - the

${ }^{129}$ See, e.g., Stern, supra note 11 , at 377-78. 
decision to strip away Fourth Amendment protection (as not objectively reasonable) creates no more clarity than would the decision to afford such protection. ${ }^{130}$ The doctrine does serve a notice function, however, by informing all parties - whether suspects or not-that this information is open to police inspection. What is made clear in advance to the police is also, by the same token, made clear in advance to those whose activities generated the records in the first place. This is particularly true in an era of television shows that constantly exhibit forensic evidence, and that weave their plots around the legal rules governing its admissibility. The writers may sometimes get the science and the doctrine wrong, but the plots often traffic in information compliantly produced by service providers of all sorts, and through sheer repetitive force these examples help to broadcast the message that viewers should accustom themselves to the possibility of police scrutiny of such information and activities.

In this sense, perhaps, the "CSI effect" might be better understood not as a vehicle for hindering criminal prosecutions when no forensic evidence is available, ${ }^{131}$ but as a means of informing viewers (including those who will never serve on juries) about the potentially unprotected status of their third-party transactions. All of this is to say that the communicative effects of Fourth Amendment doctrine, here involving its ability to give clear notice about what falls outside its purview, are transmitted not only to officers seeking guidance about where they may search, but also to the population at large. ${ }^{132}$ The doctrinal

${ }^{130}$ See supra, text accompanying notes 85 to 89 .

131 For an analysis of the "CSI effect," suggesting that "people who watch such television programs regularly expect better science than what they often are presented with in courts," see N.J. Schweitzer and Michael J. Saks, The CSI Effect: Popular Fiction About Forensic Science Affects the Public's Expectations About Real Forensic Science, 47 Jurimetrics J. 357 (2007). For critical discussions of this view, see Hon. Donald E. Shelton et al., An Indirect-Effects Model of Mediated Adjudication: The CSI Myth, the Tech Effect, and Metropolitan Jurors' Expectations for Scientific Evidence, 12 Vand. J. Ent. \& Tech. L. 1 (2009); Simon A. Cole \& Rachel Dioso-Villa, Investigating the "CSI Effect" Effect: Media and Litigation Crisis in Criminal Law, 61 Stan. L. Rev. 1335 (2009); Tom R. Tyler, Viewing CSI and the Threshold of Guilt: Managing Truth and Justice in Reality and Fiction, 115 Yale L.J. 1050 (2006).

${ }^{132}$ For related discussions, see Blake Ellis Reid, Substitution Effects: A Problematic Justification for the Third-Party Doctrine of the Fourth Amendment, 8 J. Telecomm. \& High Tech. L. 613, 625 (2010) ("the third-party doctrine, even if it works as advertised [in Kerr's analysis], may problematically preclude innocent citizens, not just criminals, from opportunistically substituting private acts for public. Furthermore, the third-party doctrine may induce innocent citizens to avoid socially productive uses of technology--perversely causing inverse substitution effects.); Richard Epstein, Privacy and the Third Hand: Lessons from the Common Law of Reasonable 
message is conveyed to the watchers and the watched alike. Foucaultian readings of novels, such as Miller's, often raise questions about whether fiction articulates these messages clearly enough, or whether the genre is culturally pervasive enough, to produce the effects that literary critics have discerned. These objections would seem to have less bite in the context of the third-party doctrine. The substitutive theory suggests that the third-party doctrine, by virtue of the exante clarity it creates, tells everyone in its purview that they ought to regard themselves as under surveillance whenever they engage in conduct that may be deemed "public" under the Fourth Amendment.

In sum, whatever one may think about the justificatory force of Kerr's theory, it provides a compelling description of the effects of the third-party doctrine. The study of narrative perspective is useful, in this context, not because it can show us how to revise the doctrine or how to establish a sounder empirical footing for "reasonable expectations of privacy," but because it shows why the doctrine works so effectively in its current form, why it makes sense to associate the doctrine with substitutive conduct. The distinction between focalized and omniscient narration alerts us to the ambiguity surrounding conduct whose dual nature - seemingly private but legally deemed to be public - is the feature that gives the police access to otherwise unobservable details. Taken together, the substitutive account and the argument from ex-ante clarity bring us to largely the same conclusions as the narrative approach. They show us how the third-party doctrine declares certain activities public, but relies for its efficacy on their seemingly private nature.

\section{CONClusion: OMniscience WiThout CERTAINTY}

Since the advent of literary modernism, omniscient narration has fallen in disfavor. In its confident pronouncements, panoramic vision, and assumption of indisputable authority, this narrative mode betokens a view about the possibility of certain and complete knowledge that writers and readers have rejected as unsupportable. This attitude is summed up in influential theory of narrative: "[T]he authoritarian monism of the fully omniscient mode of narration has become less and less tenable in modern times, while [a] multifarious relativism . .

Expectations, 24 Berk. Tech. L.J. 1999, 1226 (2009) (under the substitutive theory, "the inability to substitute creates social inefficiencies with respect to lawful conduct that people naturally wish to keep from the prying eye of the state."). 
. has seemed increasingly appropriate." perspectivism, in which all claims to authority are suspect, the omniscient narrator is an archaism to be patronized when he is found in the works of the past and to be scorned when he appears in contemporary work."134 Given the turn away from an all-seeing, implicitly trustworthy observer, it might seem doubtful that the narrative analogy pursued above can have much explanatory power, if applied to contemporary fiction.

One way to reconsider the analogy would be to emphasize the limits that even the third-party doctrine cannot overcome. It was noted earlier that whereas literary characters are not usually taken to exist on the same level as their authors, the prisoners and guards in Bentham's panoptical model can (at least potentially) perceive each other; this difference suggests a limit to the kind of control and certainty that the model affords, outside the sphere of fiction. ${ }^{135}$ The turn away from narrative omniscience, then, might be seen as a turn towards a narrative model that more accurately matches the practical application of the third-party doctrine, because despite its space- and time-traveling effects, it functions in a world where the investigators and suspects inhabit the same plane, where records are subject to interpretation, and where some information remains inaccessible. Even the doctrine's substitutive effects cannot give the police perfect knowledge, and so the better analogy might seem to involve a narrative stance that expresses the partiality of any observer's perspective, including the partiality of the observer's experience, capacities, and inclinations.

This approach would highlight an easily overlooked aspect of third-party documents - namely, their status as human products that, by virtue of the assumptions that went into their creation, may give only a limited or distorted picture, even while seeming to be unmediated records of the events they

133 Robert Scholes \& Robert Kellogg, The Nature of Narrative 276 (1966). Scholes and Kellogg add, "A narrator who is not in some way suspect, who is not in some way subject to ironic scrutiny is what the modern temper finds least bearable." Id. at 277.

${ }^{134}$ Eugene Goodheart, Novel Practices: Classic Modern Fiction 1 (2004), quoted in Dawson, supra note 18, at 143. See also Kent Puckett, Bad Form: Social Mistakes and the Nineteenth-Century Novel 7-8 (2008) (observing that hostility to narrative omniscience reflects a sense that "the idea of omniscience is an insult both to readers and to the characters who live under its fantastic thumb ... . [B]ecause it manages to mix the varied effects of structural perfection and social authority, the idea of omniscience is especially suited to provide feelings of inferiority, guilt, and aggression in characters and readers alike.").

${ }^{135}$ See supra, text accompanying note 100. 
commemorate. Like certain kinds of visual evidence (photographs, fingerprints), third-party evidence may appear perfectly legible and not open to dispute, but as Jennifer Mnookin has observed, even seemingly clear and crisp visual evidence is often semi-legible - "neither fully opaque nor fully transparent"-and hence "subject to question, doubt, and ambiguity, capable of being understood differently by others." ${ }^{136}$ One of the features that explains this quality involves the situated stance from which the evidence is produced: for example, "the surveillance camera may pan away at a critical moment, or capture the image of the victim but not the perpetrator."137 Like these potentially deceptive forms of visual evidence, the third-party doctrine might be associated with information that manages, because of its range and apparent infallibility, to seem like perfect knowledge, while actually being constrained by the circumstances of its production. The untrustworthy narrator of modernist fiction might therefore seem a more promising figure to sponsor this doctrine.

That response, however, would be just as ill-advised as an unhesitating endorsement of the analogy furnished by the omniscient mode in its classic form. Evidence collected from service providers is not unusually likely to provoke disputes about its meaning or accuracy - the same problems arise with documentary evidence obtained from witnesses or by means of a properly executed warrant. What distinguishes third-party evidence is not its failure to be transparent or unimpeachable, but the manner of its production. No one has ever been constrained to argue, when explaining why the police are entitled to evidence delivered pursuant to a warrant, that they are simply being given the same information they could otherwise have obtained directly. When considered as serving a substitutive function, the third-party doctrine puts this evidence on a different footing through the magic of just-in-time record production, which has the restorative effect of placing the police at a wide variety of temporal and spatial locations. While the metaphor of the untrustworthy narrator is a helpful reminder of the contingencies associated with any evidence that appears to "speak for itself," it would fail to capture the ubiquitous power of the police under the thirdparty doctrine, instead restricting the narrative perspective to a single figure.

${ }^{136}$ Jennifer Mnookin, "Semi-Legibility and Visual Evidence: An Initial Exploration,” Law, Culture and the Humanities 1, 5 (2012) (OnlineFirst version available at: http://lch.sagepub.com/content/early/2012/03/08/1743872111435998.full.pdf+html).

${ }^{137}$ Id. at 12. 
In a recent essay on forms of omniscience in contemporary fiction, Paul Dawson detects a return to the wide-ranging, mind-reading abilities of the nineteenth-century narrator, but without the "luxury of being spokespersons of authority, asserting accepted truths on behalf of a general consciousness."138 Whatever authority these contemporary narrators have "is based less on traditional novelistic convention accepted by a unified reading public, than on other extraliterary claims to knowledge or expertise in postmodern culture." 139 Dawson finds early anticipations of this tendency in fiction and critical commentary published in the late 1960s, around the time of Katz, ${ }^{140}$ and in categorizing the forms it has taken over the last twenty years, he includes the recent fiction of Tom Wolfe, Jonathan Franzen, and Don DeLillo. ${ }^{141}$ In novels by these writers, the reader has access to the characters' consciousness in the fashion of an earlier literary era; however, the narrator does not simply don the mantle of authority but must earn it. "[O]mniscient authority must be granted by the reading public, rather than unselfconsciously assumed by the narrator[;] 'allknowing', in this case, has come to mean less a divine or telepathic knowledge of the human interior, than a polymathic knowledge of how the world works."142 This stance, Dawson observes, casts " $[\mathrm{t}]$ he narrator as immersion journalist, . . . a fictional counterpart of the narrators of documentary novels, such as Truman Capote's In Cold Blood, . . . stem[ming] directly from the New Journalism."143 This voice displays a significant degree of self-consciousness about the grounds of any authority that the narrator may claim, suggesting a willingness to concede its limits while nevertheless displaying the superhuman abilities conventionally associated with omniscient narration. It is a narrative voice emanating from an identifiable figure endowed with human traits, attempting to master the doubts

\footnotetext{
${ }^{138}$ Dawson, supra note 18 , at 150.

${ }^{139}$ Id. at 149.

${ }^{140}$ For example, Dawson cites the narrator's observation, in John Fowles's 1969 novel The French Lieutenant's Woman, that "[w]e suspect people who pretend to be omniscient; and that is why so many twentieth-century novelists feel driven into first person narration." Id. at 152 . He also points to "David Lodge's important 1969 essay, 'The Novelist at the Crossroads," as a response to widespread reports of "the death of author" — a response that identified "examples of postmodern experimentation with form which opened up the possibility for re-introducing omniscient narration in literary fiction." Id.

${ }^{141} \mathrm{Id}$. at 155.

${ }^{142} \mathrm{Id}$.

${ }^{143}$ Id. Capote's book, sometimes called a "nonfiction novel," was originally published in 1966, a year before Katz was decided.
} 
and ambiguities that undermine its quest for certainty, and leaving it to the reader to decide whether those efforts are successful.

Thus during roughly the same period same period in which Katz produced the "reasonable expectation" test and revamped the Fourth Amendment to cover "people, not places," "144 we have seen a renewed fascination in literary fiction with some of the powers, though not the indubitable authority, of the omniscient narrator. Both developments are means of granting access to knowledge that no one person could claim to have, even if that knowledge is accompanied by an awareness of its limits. Whether they operate to create a similar understanding of privacy is another question. The contemporary narrator, in its most intrusive form, is no more respectful of the characters' privacy than the classic omniscient narrator would be. But a narrator whose authority must be earned, whose urge towards complete knowledge is limited, may leave readers disinclined to train the narrative gaze on themselves. The impermeable authority of the nineteenthcentury narrator is often discussed in theological terms, ${ }^{145}$ and one may suspect that with the disappearance of this effortless and pervasive control, the sense of being potentially subject to such control also disappears. On the other hand, even if the records it yields are subject to interpretation, the third-party doctrine has a remarkable ability to reach information generally seen as private - an ability that is regularly dramatized on television, and that is usually shown as operating rapidly and effectively to deliver accurate information. In an age of chastened narrative authority, this doctrine has probably come to define citizens' perceptions of privacy more forcefully than the narrative form that originally supplied its closest analogue.

${ }^{144}$ Katz, supra note 2, at 351 .

${ }^{145}$ Id. at 145,157 n.1; see also supra note 18. 